\title{
Geothermal Anomalies on the Eastern Flank of the Cherokee Basin, Southeastern Kansas, USA
}

\author{
K. David Newell ${ }^{1}$ and Tiraz R. Birdie ${ }^{2}$ \\ ${ }^{1}$ Kansas Geological Survey, University of Kansas, Lawrence, Kansas, dnewell@kgs.ku.edu \\ ${ }^{2}$ TBirdie Consulting, Lawrence, Kansas, tbirdie@tbirdieconsulting.com
}

\begin{abstract}
Bottomhole temperature measurements from oil and gas drilling in southeastern Kansas on the eastern flank of the Cherokee basin, in combination with a suite of about 2,200 differential temperature logs recently obtained from wireline logging in coalbed methane wells, define several higher-temperature anomalies at the top of the Mississippian Subsystem strata. Temperatures slightly in excess of $90^{\circ} \mathrm{F}$ ( 35 $\left.{ }^{\circ} \mathrm{C}\right)$ at depths of about $900 \mathrm{ft}(275 \mathrm{~m})$ correspond to geothermal gradients as high as about $60{ }^{\circ} \mathrm{C} / \mathrm{km}$.
\end{abstract}

Sparse historical measurements of heat flow in the cratonic Cherokee basin indicate that the thermal anomalies are not likely caused by locally high heat flow. Heat flow in the Cherokee basin is probably in line with most other shallow cratonic basins. The higher-temperature thermal anomalies defined by logging temperatures do not correspond to previously mapped faults or other structural features in the Phanerozoic sedimentary section, but some anomalies are underlain by Precambrian basement lineations that are detectable with aeromagnetic and gravity measurements. Well-log determination of shale content in the Pennsylvanian sedimentary strata overlying the Mississippian limestones indicates that low thermal conductivity caused by higher shale content may cause some of the thermal anomalies.

Lateral (advective) movement of warmer, highly saline water from the basin axis cannot account for the anomalies because the anomalies are not characterized by exceptionally highly saline water in Mississippian strata. Similarly, recorded static fluid levels of wells disposing of oilfield saltwater into the Mississippian strata and the deeper Cambrian-Ordovician Arbuckle Group indicate that the deeper Arbuckle strata generally do not have sufficient formation pressure to force Arbuckle formation water upward into the Mississippian through either natural fractures or leaky wellbores. Small-scale changes in salinity, in combination with geologic structuring indicating faulting, make a case for vertical (convective) movement of heated, less saline water from the Arbuckle Group into overlying Mississippian limestones in isolated localities. Buoyancy of the Arbuckle formation water (due to temperature and salinity differences with the cooler and more saline Mississippian water) could also be the primary force behind the convection. Convergence of cooler freshwater moving westward off the Ozark dome and more saline basinal water moving eastward also could be a factor in defining the limits of some thermal anomalies.

\section{Midcontinent Geoscience • Volume 2・December 2021}

Midcontinent Geoscience is an open-access, peer-reviewed journal of the Kansas Geological Survey. The journal publishes original research on a broad array of geoscience topics, with an emphasis on the midcontinent region of the United States, including the Great Plains and Central Lowland provinces. 


\section{INTRODUCTION}

Approximately 2,200 continuous temperature logs (also known as differential temperature logs) were obtained in drilling for coalbed methane (CBM) in the Cherokee basin in southeastern Kansas since 1995. These wells were mostly air drilled, and their objectives were several thin coal seams in the Pennsylvanian (mostly Desmoinesian-age Cherokee and Marmaton Groups) at depths from 800 to $1,250 \mathrm{ft}$ (250 to $375 \mathrm{~m}$ ). Total depths (TDs) for most of these CBM wells are usually in Mississippian strata that lie slightly unconformably beneath the Pennsylvanian.

In the differential temperature $\log$, a continuous temperature curve over the entire depth of the well is usually presented in one track and a differential temperature curve (i.e., a curve that quantifies the change in temperature with each foot) is presented in a separate track. A gamma-ray curve and sometimes a neutronporosity curve are common companion curves to the temperature curves.

The close geographic spacing of CBM wells (as many as 100 wells per township; with each township being 36 square miles [93 sq. km]) allows for unprecedentedly detailed mapping of subsurface temperatures and geothermal gradients. Temperatures in Mississippian strata derived from differential temperature logs, combined with older and concurrent bottomhole temperature (BHT) measurements from oil and gas wells drilled to the Mississippian, show that some regions on the eastern flank of the Cherokee basin have temperatures in excess of $90{ }^{\circ} \mathrm{F}\left(35^{\circ} \mathrm{C}\right)$ at subsurface depths of 900 to $1,000 \mathrm{ft}(275$ to $300 \mathrm{~m}$ ). Calculated geothermal gradients at the top of the Mississippian can be as high as $60^{\circ} \mathrm{C} / \mathrm{km}$, which is well in excess of the worldwide geothermal gradient of 26 ${ }^{\circ} \mathrm{C} / \mathrm{km}$ (as conveyed by Selley, 1998, p. 155) and the mean continental lithospheric geothermal gradient of $30^{\circ} \mathrm{C} / \mathrm{km}$ (Allen and Allen, 2013, p. 32). These regions of apparently high geothermal gradient can cover several townships, equivalent to $450-600$ square miles (750-1,000 sq. km).

The ultimate source of the heat is radioactivity in the Precambrian crystalline basement. The basement in this part of the midcontinent is composed of east-west trending accretionary terranes that are progressively older northward. The Cherokee basin (fig.1) sits atop the Hitchcock terrane $(1.67 \mathrm{Ga}$ ) and Western Kansas terrane $(1.61 \mathrm{Ga})$. Younger granitic bodies $(1.34 \mathrm{Ga})$ intruded into the Hitchcock terrane (Carlson and Treves, 2005). Movement of the heat generated in the basement rocks can occur by several means: (1) conduction, (2) upward movement (convection) of formation water along faults and fractures, (3) eastward lateral movement (advection) from the warmer center of the Cherokee basin, or (4) northward lateral movement from the Arkoma basin in Oklahoma. Various fluxes of subsurface water from various sources have moved through the basin over geologic time (cf., Wojcik et al., 1994, 1997; Foerster et al., 1998; Merriam, 1999), but this report concentrates on the presentday thermal architecture of the basin. Effects of thermal conductivity of the Pennsylvanian strata and its influence on temperatures in the underlying Mississippian strata are specifically investigated.

\section{GEOLOGIC SETTING}

Kansas is in the stable cratonic interior of the midcontinent United States. Two shallow structural basins - the Forest City basin in the northeastern part of the state and the Cherokee basin in the southeast - contain approximately 1,500 to $4,500 \mathrm{ft}$ (450 to $1,375 \mathrm{~m}$ ) of Paleozoic sedimentary strata (fig. 1). These basins have broad eastern flanks where west-northwestward dips of Pennsylvanian, Mississippian, and older Phanerozoic strata are on the order of $20 \mathrm{ft}$ per mile (about $4 \mathrm{~m}$ per $\mathrm{km}$ ). The western flanks of both basins are steeply dipping and faulted due to late-Mississippian to early Pennsylvanian structural movement associated with the developing south-southwestward plunging Nemaha uplift (Merriam, 1963).

The Cherokee basin in southeastern Kansas is a shallow northward extension of the Arkoma basin in Oklahoma (Merriam, 1963). The maximum sedimentary thickness (all Paleozoic strata) is about $4,500 \mathrm{ft}(1,375 \mathrm{~m})$ and is situated in the north-northeast-south-southwest trending axis of the basin in southern Cowley County, immediately north of the Kansas-Oklahoma state line. The Paleozoic section thins eastward to a thickness of about 1,500 $\mathrm{ft}(450 \mathrm{~m})$ in the southeastern corner of the state in Cherokee County, 120 miles $(193 \mathrm{~km})$ east.

\section{STRATIGRAPHY}

Gently west-northwestward dipping Pennsylvanian and Permian strata crop out at the surface in eastern Kansas, except for a small area in the extreme southeastern part of the state where Mississippian strata are exposed (fig.1). Mississippian formations exposed at the surface are Burlington-Keokuk and Warsaw Limestones, but these units are not easily differentiated in the subsurface. Pennsylvanian (Desmoinesian) strata unconformably overlie the Mississippian limestones at low angles (generally less than $5^{\circ}$ ). Much of the Desmoinesian strata, particularly the Cherokee and Marmaton Groups (fig. 2), 
Figure 1. (A) Regional structural features of the midcontinent United States. (B) Structural features of Kansas and the study area (red box) in southeastern Kansas in the Cherokee basin. Structural features in the study area (from Merriam, 1963) are identified. The red dashed line in the study area is a sharp, high-frequency boundary defined by Yarger (1983) using processed aeromagnetic data. This boundary may be the tectonic suture between the Hitchcock accretionary terrane $(1.67 \mathrm{Ga})$ to the north and the Western Kansas accretionary terrane $(1.61 \mathrm{Ga})$ to the south (see Bickford et al., 1981; Carlson and Treves, 2005). (C) Geologic map of the study area (from Kansas Geological Survey, 2020a). Progressively younger Pennsylvanian strata are exposed west-northwestward, as these strata gently dip westnorthwestward off the Ozark dome into the Cherokee basin. Mississippian limestones are exposed in the extreme southeastern corner of the state.
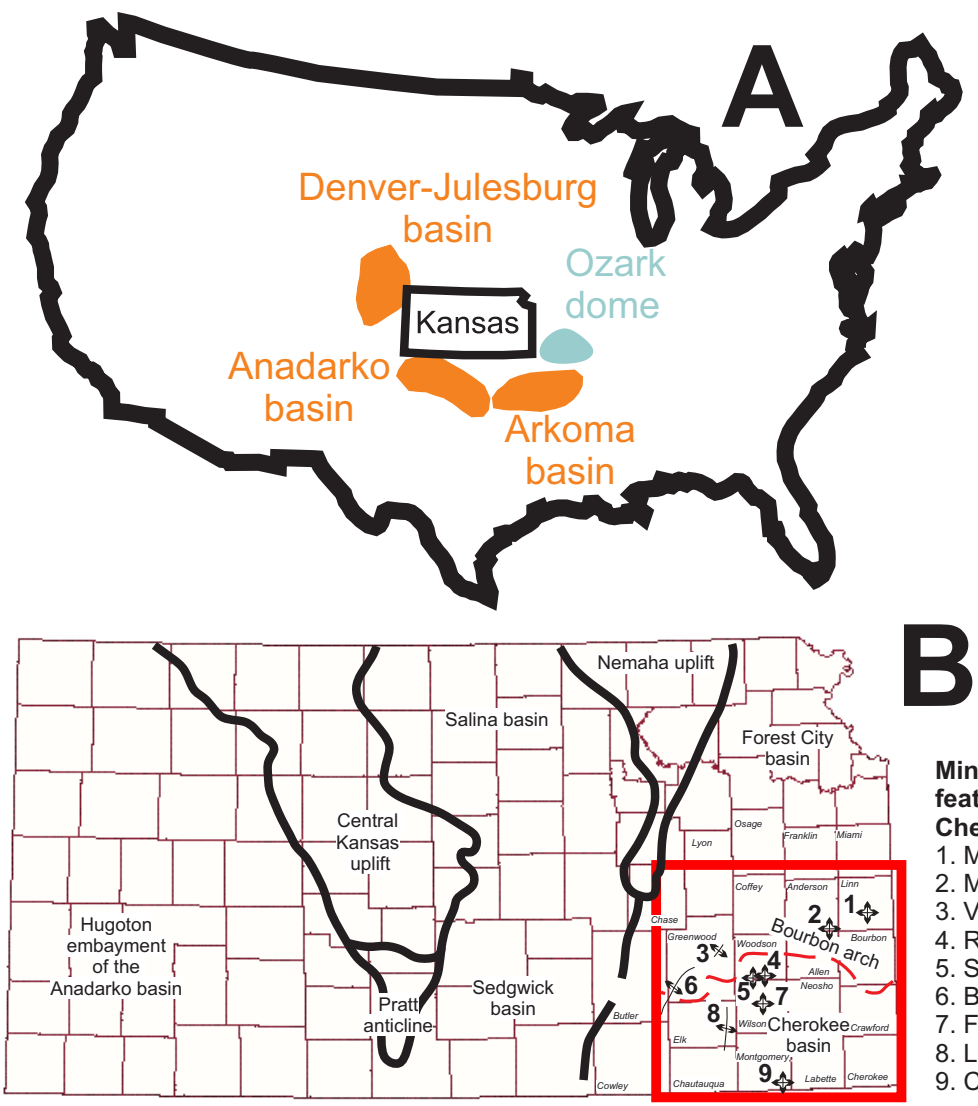

Minor structural features in Cherokee basin 1. Mound City dome 2. Mildred dome 3. Virgil anticline 4. Rose dome 5. Silver City dome 6. Beaumont anticline 7. Fredonia dome 8. Longton anticline 9. Coffeyville dome

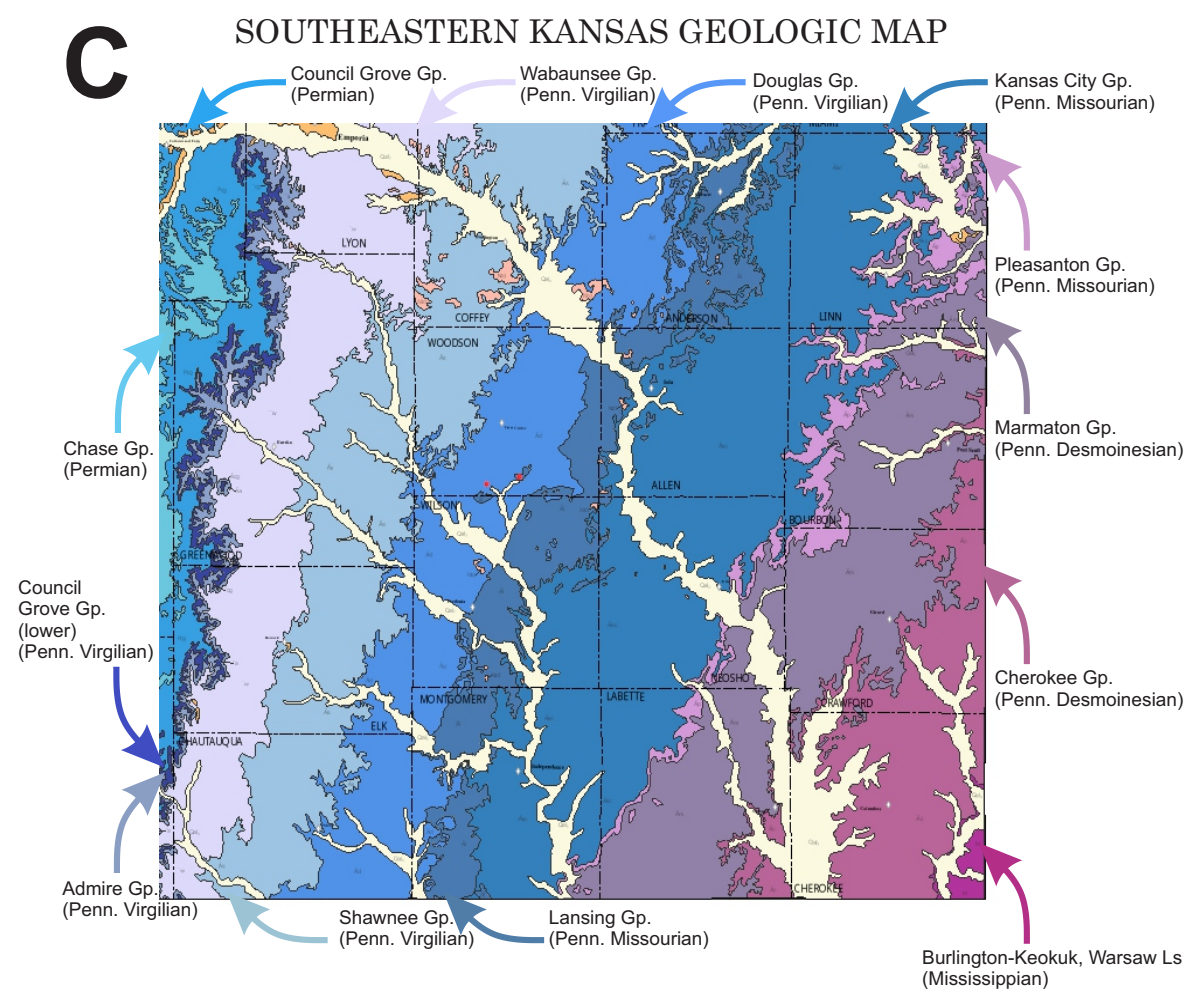




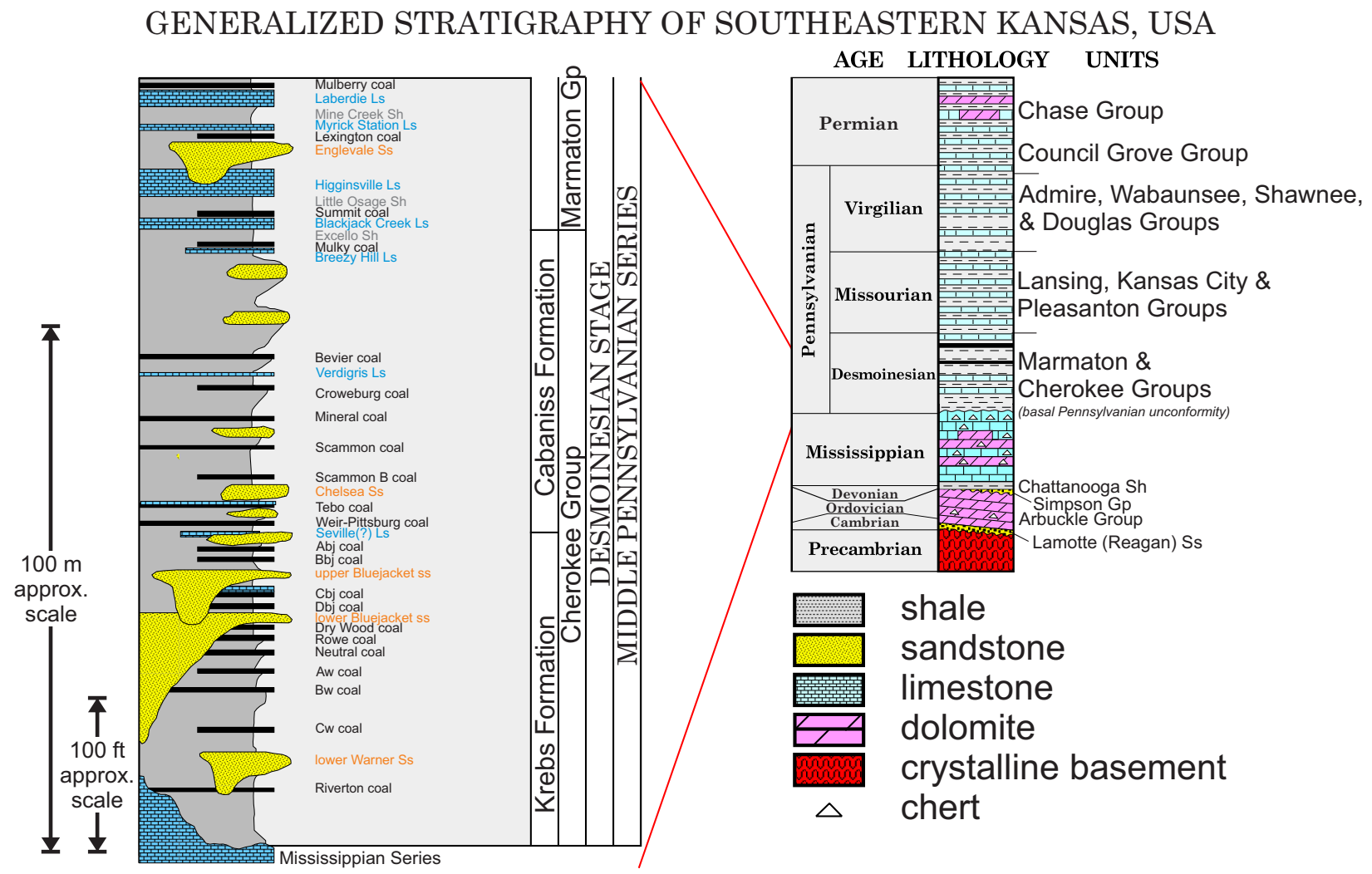

Figure 2. Generalized stratigraphy of southeastern Kansas (from Newell and Merriam, 2013). Over much of the study area in southeastern Kansas, Devonian-Mississippian Chattanooga Shale lies directly beneath Mississippian limestones and directly over the Cambrian-Ordovician Arbuckle Group. Normally intervening Ordovician, Silurian, and Devonian strata have been eroded off the top of a regional early Paleozoic uplift called the Chautauqua arch (Merriam, 1963).

are coal-bearing strata composed dominantly of shale, with subsidiary sandstones and thin limestones. In turn, the Desmoinesian-age strata are overlain by Missourian- and Virgilian-age cyclothemic strata (Lansing-Kansas City, Douglas, and Shawnee Groups) composed of alternating shales and limestones interspersed with minor sheet and channel sandstones (fig. 2).

Mississippian strata in southeastern Kansas are about $300 \mathrm{ft}(90 \mathrm{~m})$ thick and composed of limestone and dolomites of the Burlington-Keokuk and Warsaw Limestones (Bennison, 2002; Kansas Geological Survey, 2020a). Much of it is porous and, as such, comprises the upper unit of a largescale fresh and saline aquifer system that covers southern Missouri, eastern Kansas, and northeastern Oklahoma (Carr et al., 1986; Macfarlane and Hathaway, 1987; Jorgensen, 1989; Jorgensen et al., 1993, 1996; Carr et al., 2005). This aquifer system is known as the Ozark Plateau (OP) aquifer system. The lower part of this system is composed of lower Paleozoic rocks - Cambrian Lamotte (Reagan) Sandstone overlain by Cambrian-Ordovician dolomitic carbonates of the Arbuckle Group (Merriam, 1963). Freshwater dominates the aquifer near the state line in southeastern Kansas, but the salinity of the aquifer rises markedly westward to in excess of 100,000 parts per million total dissolved solids (ppm TDS) in the Cherokee basin.

The Devonian-Mississippian Chattanooga Shale, which is about $50 \mathrm{ft}(15 \mathrm{~m})$ thick in southeastern Kansas, lies between the Mississippian limestones and the CambrianOrdovician Arbuckle Group. Normally, Devonian, Silurian, and Middle Ordovician strata underlie the Chattanooga Shale, but these strata were eroded atop a broad postSilurian-pre-Devonian uplift formed prior to the presentday Cherokee basin (Merriam, 1963). This uplift, called the Chautauqua arch, causes the Chattanooga Shale to unconformably overlie the Arbuckle Group over much of the study area. In the Cherokee basin farther west of the outcrop in extreme southeastern Kansas (see fig. 1), the presence of the Chattanooga Shale divides the OP aquifer system into two hydrologically separate units (Goebel, 1968b) composed of Mississippian-age strata and the Arbuckle Group. The Arbuckle Group is 700 to 1,100 ft (200 to $325 \mathrm{~m}$ ) thick in Kansas. It is a regional saltwaterfreshwater aquifer and oil and gas reservoir composed mostly of vuggy and fractured dolomite (Goebel, 1968a, 
c). It lies on the Precambrian crystalline basement, with only a few feet of intervening Cambrian Lamotte (Reagan) Sandstone being locally present.

\section{OIL AND GAS}

Most oil and gas fields in the Cherokee basin in southeastern Kansas were discovered before 1920 (Newell et al., 1987).

Pennsylvanian sheet and channel sandstones account for most of the petroleum production, but Mississippian limestones and dolomite in the Cambrian-Ordovician Arbuckle Group account for localized hydrocarbon accumulations in the western part of the study area (Newell et al., 1987). The Cherokee basin is thus a venerable producing area now dominated by stripper well production (i.e., less than 5 barrels / day) (Carr, 2004). CBM exploration and production drilling from 1995 to 2009 (see fig. 3) temporarily revitalized the region, but drilling for this resource all but ceased with a dramatic fall of natural gas prices starting in mid-2008, when wellhead prices fell from $\$ 10.79$ per thousand cubic ft (mcf) in July 2008 to $\$ 3.18 / \mathrm{mcf}$ in April 2009 (U.S. Energy Information Agency, 2020). The CBM industry has yet to recover, and few CBM wells have been drilled in Kansas in the last decade (i.e., 2010 to 2020). Nevertheless, existing CBM wells in the Cherokee basin have cumulatively produced about $500 \mathrm{BCF}$ of natural gas from approximately 7,000 wells (Newell, 2017).

The CBM gas resource is contained in several thin coal seams at depths from 800 to $1,250 \mathrm{ft}$ (250 to $375 \mathrm{~m}$ ) (see Newell and Carr, 2009; Newell and Yoakum, 2010). Up to 14 seams can be penetrated in a given well, and most coals are less than 28 inches $(71 \mathrm{~cm})$ thick (Brady, 1997) (fig. 2). The vast majority of the CBM wells in the Cherokee basin are vertical wells that are completed in several coal beds (Newell, 2017). Most of the CBM wells have TDs in Mississippian limestones. Saltwater disposal wells are drilled 200 to $400 \mathrm{ft}$ (60-120 m) deeper for fluid disposal into the Arbuckle Group.

\section{TEMPERATURE MEASUREMENT}

\section{CBM Drilling}

Many of the CBM wells were drilled differently from earlier wells, in that the CBM wells were mostly air drilled using rotary percussion drill bits. Most earlier wells were drilled using rotary rigs with drilling mud, and cable tools were used prior to the advent of the rotary rig. Wells drilled by rotary rigs using mud could take a few days to reach $\mathrm{TD}$, and thus a well-log bottomhole temperature (BHT) would almost always represent an unequilibrated temperature somewhat less than true formation temperature. Air-drilled wells could be drilled in about one day. Upon reaching TD, formation water, usually from porous Mississippian carbonates at the bottom of the hole, would then quickly fill the hole. This water was probably drawn from strata beyond the thermally unequilibrated rock immediately adjacent to the wellbore.

The quicker drilling time and the flooding of the hole by formation water both serve to minimize the disequilibrium in temperature between the hole and the surrounding formation in the air-drilled holes, but temperatures obtained from air-drilled wells probably are still unequilibrated. Some wells drilled in the heat of the summer show the influence of the warm weather in the upper parts of the hole (see figs. 4-5), but depths in excess of 350 to $650 \mathrm{ft}$ (100 to $200 \mathrm{~m}$ ) generally show

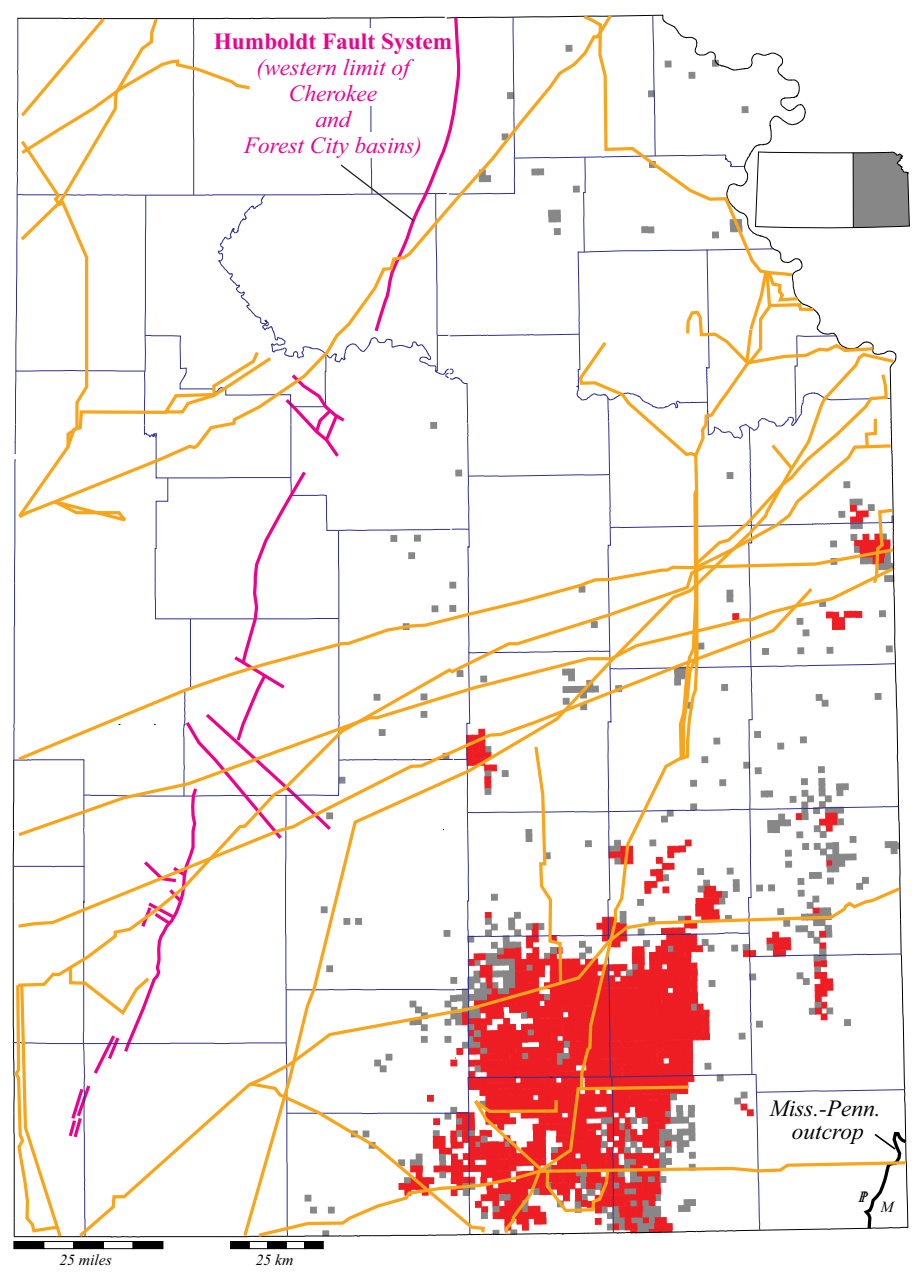

Figure 3. Locations of sections (nominally 1 by 1 mile [ 1.61 by $1.61 \mathrm{~km}]$ ) in eastern Kansas with a record of CBM production (red) and with at least one well drilled for CBM but no production recorded (gray) (after Newell and Yoakum, 2010). The Humboldt Fault System, marking the western boundary of the Cherokee and Forest City basins, is in magenta; major gas pipelines are in orange. Differential temperature logs were run on many of the CBM wells in southeastern Kansas. 


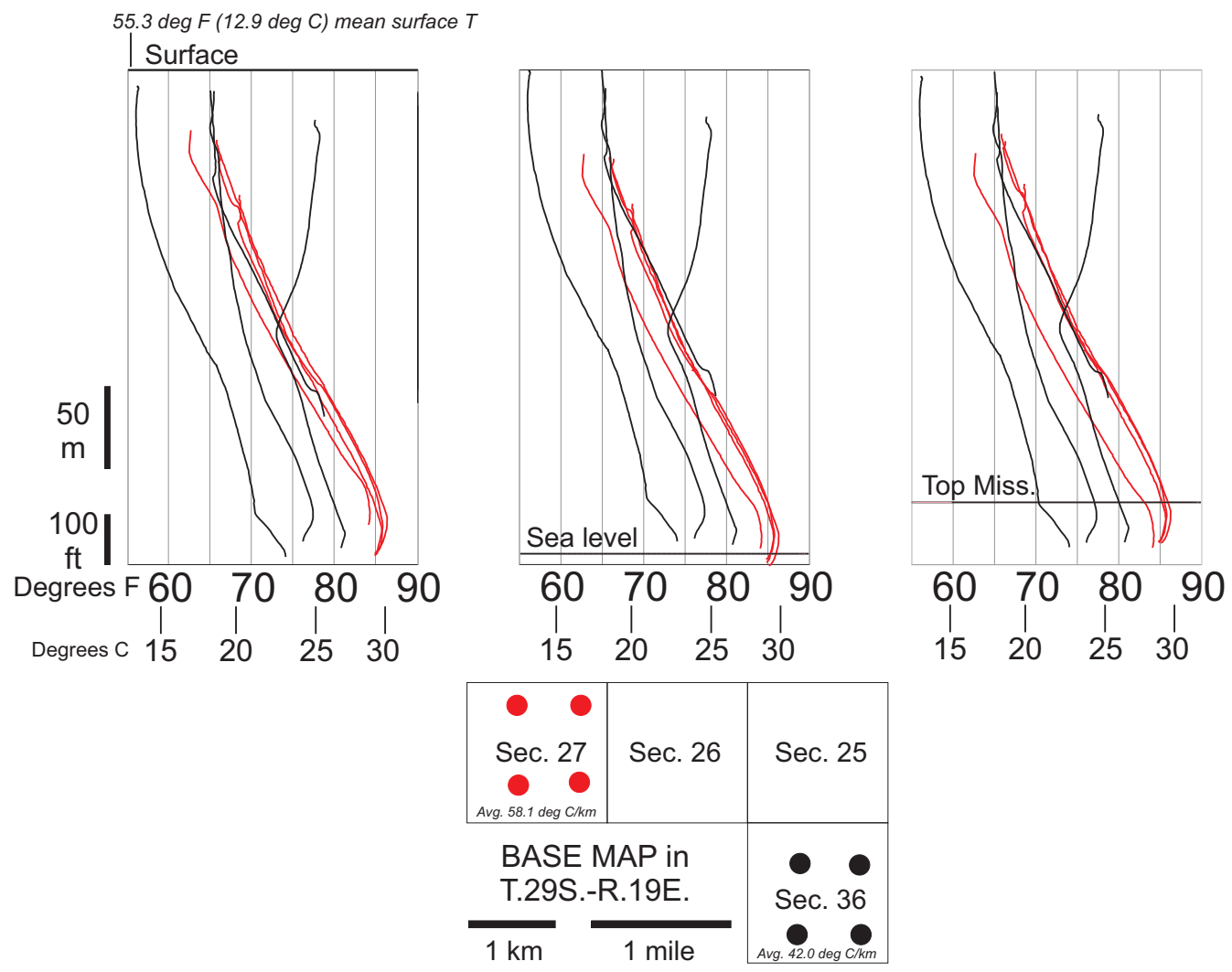

Figure 4. Comparison of CBM wells drilled in two nearby sections with markedly different average geothermal gradients of $42.0^{\circ} \mathrm{C} / \mathrm{km}$ (sec. 36 , gradients shown in black) and $58.1^{\circ} \mathrm{C} /$ $\mathrm{km}$ (sec. 27, gradients shown in red). Three different datums are presented for the temperature curves: (A) surface, (B) sea level, and $(C)$ top Mississippian. See text for discussion. steadily increasing temperatures, which indicates that the formation temperature of the rock surrounding the hole becomes more of an influence on the temperature of the water filling the hole than the temperatures imparted by the drilling process or at the surface. Ideally, to assure complete thermal equilibrium between the fluid in the hole and the surrounding geologic formation, a well should be idled for several days, or even weeks (Blackwell and Steele, 1989), before temperatures are obtained. Such down time, however, is not a luxury afforded to an industrial drilling program. Only six wells assuredly equilibrated with the strata in which they are drilled have been subjected to precision temperature logging in southeastern Kansas (see Blackwell and Steele, 1989).

Wireline logging in a recently drilled CBM well usually commences hours after drilling ceases, so the temperatures obtained either with a BHT measurement or a differential temperature log are not yet equilibrated with true formation temperature. This is a problem, but mapping presented in this paper indicates that coherent spatial and stratigraphic patterns of subsurface temperatures and geothermal gradients can still be discerned. Data scatter is still evident, implying some thermal disequilibrium between the drill bore and the surrounding geologic formations; however, the scatter is somewhat ameliorated by averaging several temperature and geothermal gradient measurements obtained over a small mapping area. Individual sections (nominally 1 by $1 \mathrm{mi}$ [ 1.61 by $1.61 \mathrm{~km}]$ ) - a geographic construct of the Public Land Survey System - were chosen as the basic mapping area over which temperatures (obtained from both BHT measurements and temperature logs) and resultant geothermal gradients were averaged.

\section{Differential Temperature Logs}

Many of the CBM wells were wireline logged with modern logging suites (i.e., usually shallow, medium, and deep induction resistivity logs, neutron-porosity, densityporosity, gamma ray). A regional logging company in Chanute, Kansas, offered a differential temperature tool as a low- or no-cost supplement to the logging suite specified by their clients (L. Weis, personal communication, 2012). Approximately 2,200 continuous temperature logs from CBM wells were obtained for this study. Scans of these logs are now archived at the Kansas Geological Survey Data Resources Library and available online at the KGS website (https: / / www.kgs.ku.edu/Magellan/Qualified / index.html).

The continuous temperature profile typically increases gradually from the surface through the entire Pennsylvanian section and then markedly increases immediately below the top of the Mississippian (fig. 4). The maximum temperature recorded on the differential 
temperature logs is usually recorded within Mississippian limestones near the TD of the well. This maximum temperature and its associated depth were used to calculate geothermal gradients for the Mississippian. The marked increase in temperature at the top of the Mississippian suggests that the overlying shale-dominated Pennsylvanian section may act as an insulating blanket upon the
Mississippian (Blackwell and Steele, 1989). Shale has lower thermal conductivity than other major rock types (e.g., sandstone, limestone, dolomite; Blackwell and Steele, 1989).

One of the wells in sec. 36, T. 29 S., R. 19 E. (fig. 4 , in black) displays warmer temperatures that decrease downward from the surface to about $500 \mathrm{ft}$ (120 m) depth, then increase downward. This anomalous behavior could
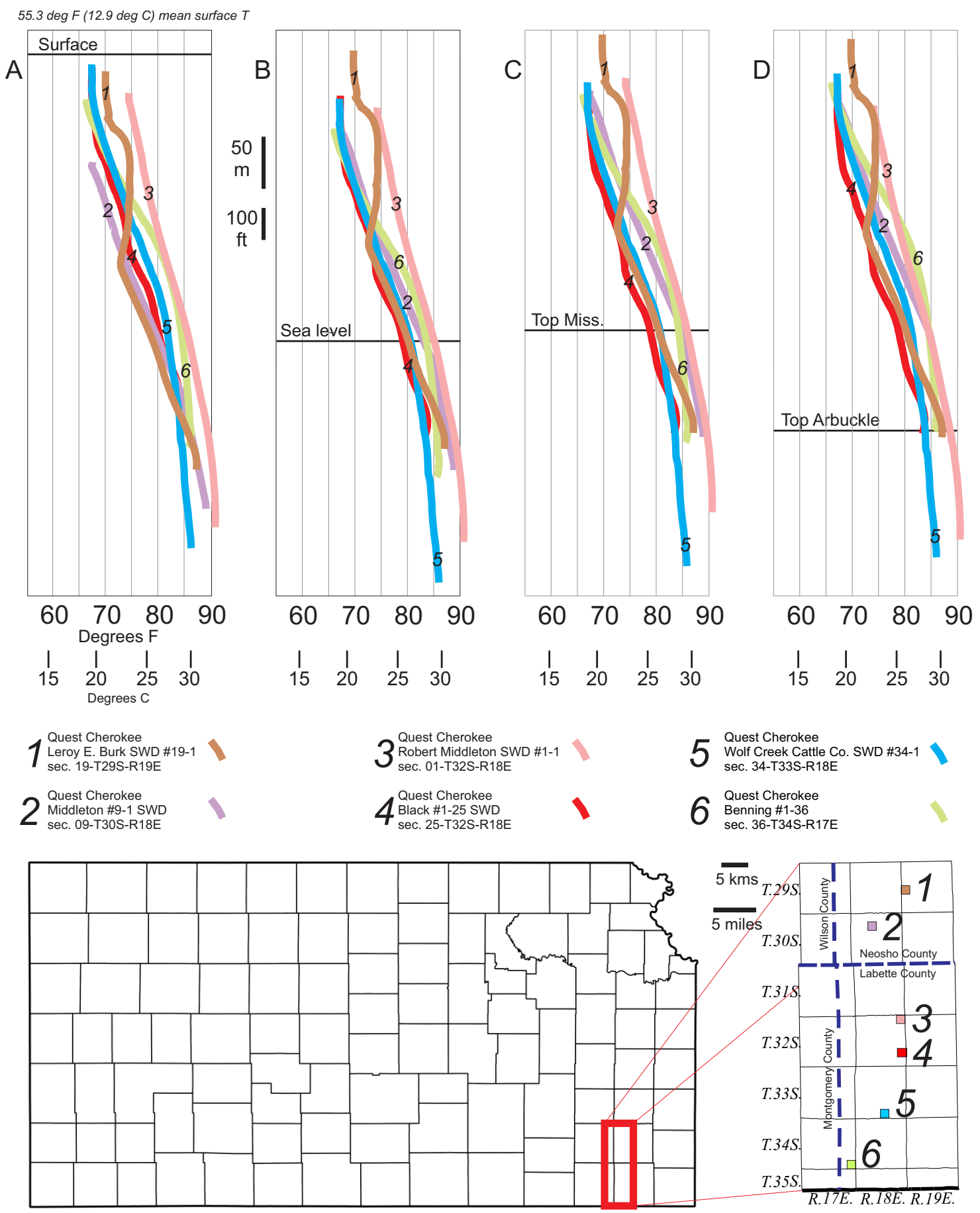

Figure 5. Comparison of temperature gradients of six deep CBM saltwater disposal wells drilled into the Arbuckle Group in southeastern Kansas. Four different datums are presented for the temperature gradients: (A) surface, (B) sea level, (C) top Mississippian, and (D) top Arbuckle. See text for discussion. 
be due to warming of the hole during the drilling process. The well was drilled in the heat of August, whereas all the other wells in both sections were drilled in cooler weather between November and March. The temperature increase below about $500 \mathrm{ft}(120 \mathrm{~m})$ conforms to temperature trends of the other wells in the section, indicating the temperature of the surrounding rock is more influential on the temperature of the wellbore in the deeper part of the well.

If a well is drilled deeper than the Mississippian (usually into the Arbuckle for brine disposal), the temperature profile usually increases downhole below the Mississippian but at a lower rate than the temperature increase in the Pennsylvanian section (fig. 5). Most of the wells in fig. 5 have a temperature gradient that slightly steepens (i.e., the change in temperature down the hole decreases within a given depth interval) just below the top of the Mississippian. Two wells — Leroy E. Burk SWD \#19-1 (well 1) and Middleton \#9-1 SWD (well 2) — were drilled and logged during the heat of July. The upper part of the Burk hole registers relatively high temperatures that appear to equilibrate more to the formation temperature at depths deeper than 650 $\mathrm{ft}(200 \mathrm{~m})$. A slight temperature inflection near the upper part of the log at $350 \mathrm{ft}(100 \mathrm{~m})$ depth in the Middleton well probably indicates that temperatures in the upper part of this well were also warmer than surrounding formations.

\section{Bottomhole Temperatures (BHTs)}

Before the recent differential temperature logs were run on air-drilled CBM wells, BHTs transcribed from log headers were the primary data for which subsurface temperature and geothermal gradients were determined for the Cherokee basin. BHTs are usually taken during logging runs at casing points during the drilling of a well, but many wells in the Cherokee basin are not wireline logged and even fewer of these wells have had BHTs taken. Most wells in eastern Kansas have only one logging run after the well has reached $\mathrm{TD}$, and most TDs are not deeper than 3,000 ft (915 m).

Typically, the temperature of the mud in a drill hole is less than true formation temperature at total depth, but at shallower depths kinetic effects of mud circulation and heat transfer from the deeper part of the well can cause mud temperatures to exceed formation temperature (Selley, 1998, p. 152). BHT data are thus generally hotter than expected in the shallow subsurface and cooler than formation temperature in the deeper subsurface. Corrections to BHT temperature measurements in eastern Kansas have been proposed (see Foerster et al., 1996). These corrections are based on depth, as time since circulation for each logging run (crucial in temperature equilibration calculations) is customarily not assiduously recorded by drilling and logging crews in this region. However, to avoid possible obfuscation of original temperature data in this study, no corrections were applied to BHT or the temperature log data.

As expected, temperatures generally increase with depth for both BHT and differential temperature logs (fig. 6). BHT data cover a greater depth range than the differential temperature measurements, but nevertheless temperatures for the two data sets appear to be on trend to each other (fig. 6) and also on trend for their derived geothermal gradients (fig. 7). Of the sections for which temperature data are available (about 850 sections in both data sets), only 53 sections have both types of data. Comparison of temperatures recorded in these few sections (fig. 8) shows a weak positive correlation. Temperatures from both data sets vary widely even within one section. Lacking any strong negative correlation, temperatures from BHTs and the temperature logs were both used in mapping subsurface temperatures in this paper, and both types of data were averaged together in those sections for which both types of data are available.

\section{SUBSURFACE TEMPERATURES IN MISSISSIPPIAN STRATA}

An early contribution to geothermal research in Kansas was a master's thesis (Stavnes, 1982) at the University of Kansas supervised by Dr. D. W. Steeples at the Kansas Geological Survey. This research and subsequent spin-off publications (Stavnes and Steeples, 1982a, b; Steeples and Stavnes, 1982) concentrated on determining subsurface temperatures and geothermal gradients for the entire state. The main source of data for Stavnes (1982) was BHTs on log headers in the thousands of wells drilled for oil and gas in Kansas, supplemented by temperature logging by the geothermal research group at Southern Methodist University (see Blackwell and Steele, 1989). Stavnes (1982) determined geothermal gradients using such depth-related criteria as, for example, temperatures from BHTs taken from wells deeper than 1,000 ft (305 m), wells deeper than $400 \mathrm{ft}(122 \mathrm{~m})$, and wells deeper than $600 \mathrm{ft}(183 \mathrm{~m})$. In contrast, the present study concentrates on temperatures and geothermal gradients determined for a specific stratigraphic interval - upper Mississippian formations - derived from BHTs and a new data set of thermally logged wells.

The pattern of geothermal gradients determined for southeastern Kansas by Stavnes (1982) was complex, and their analysis detected several areas where geothermal gradients were in excess of $50{ }^{\circ} \mathrm{C} / \mathrm{km}$. In addition, these 
A.

Bottomhole Temperatures (from Well Logs)

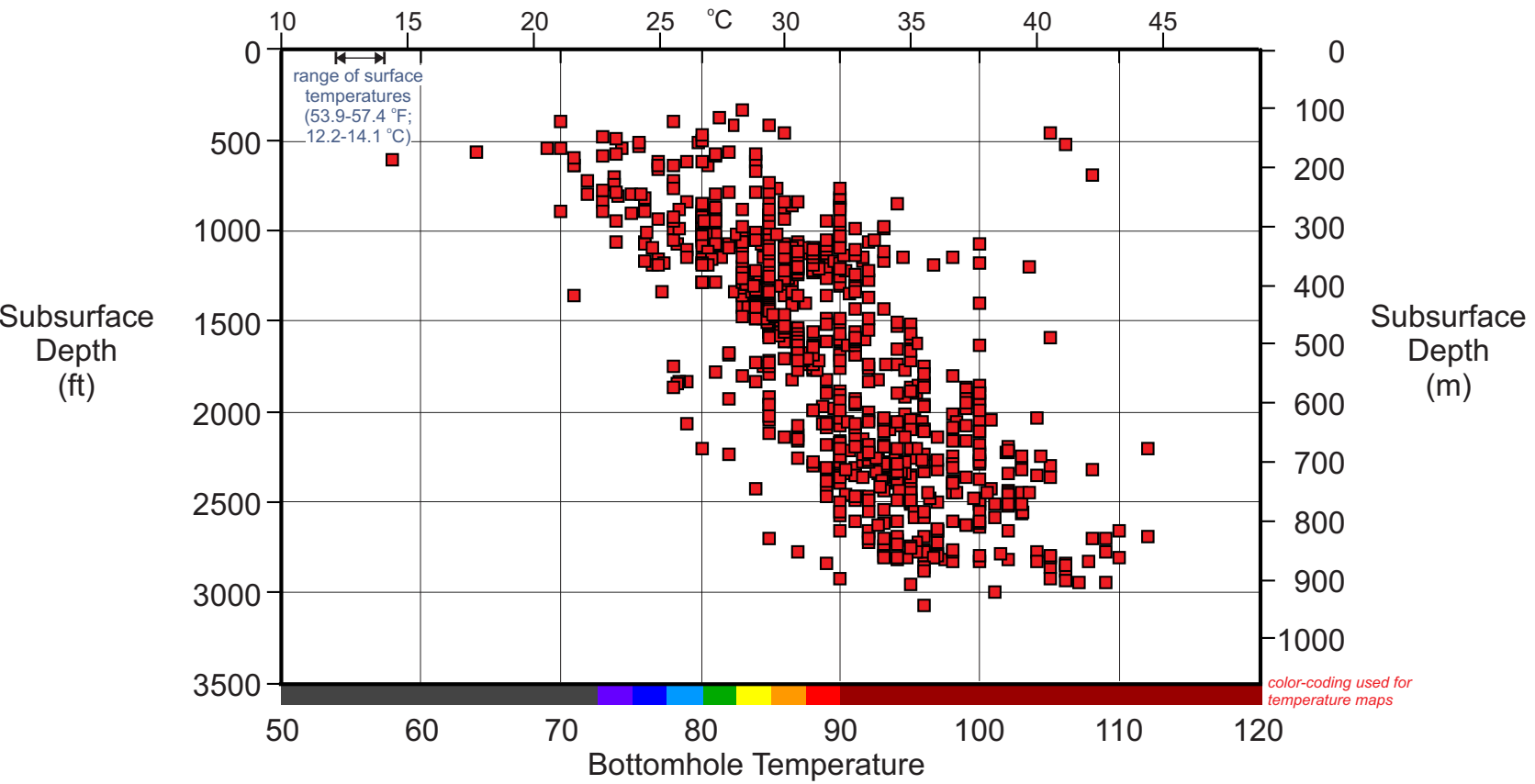

$\left({ }^{\circ} \mathrm{F}\right)$

$\square$ represents averaged temperature and averaged subsurface TD determined from all bottomhole temperatures in a section (each section is approximately 1 by 1 miles [1.61 by $1.61 \mathrm{~km}]$ )

B. Maximum Temperature (from Differential Temperature Logs) for Top Mississippian Strata vs. Subsurface Depth

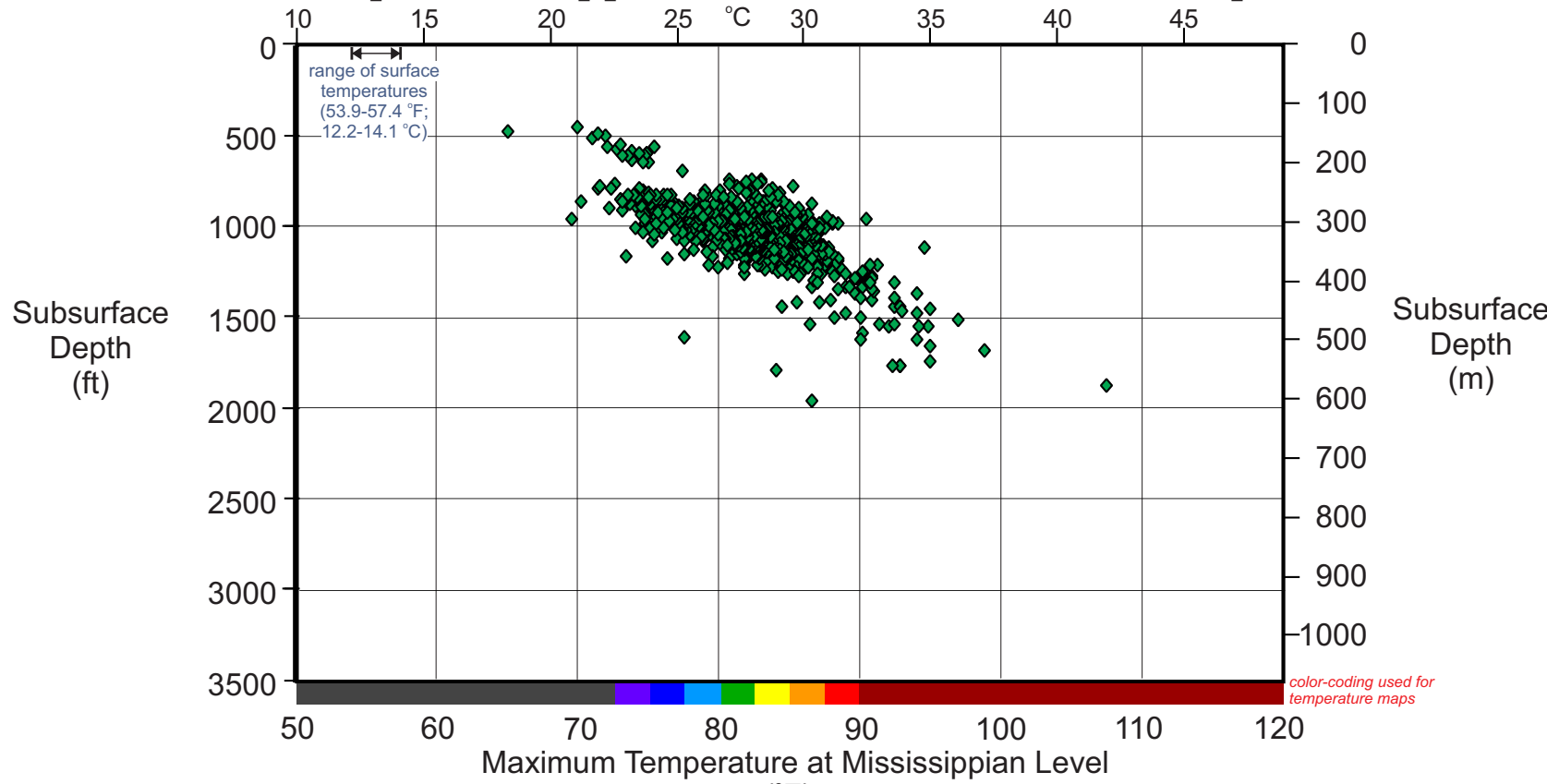

$\left({ }^{\circ} \mathrm{F}\right)$

$\checkmark$ represents averaged temperature and averaged subsurface depth recorded from all differentia

temperature logged wells in a section (each section is approximately 1 by 1 miles [1.61 by $1.61 \mathrm{~km}]$ )

Figure 6. Comparison of temperatures at the top of the Mississippian from (A) BHTs on log headers vs. (B) differential temperature logs. Each symbol represents the depths and temperatures averaged in one section. Although shallower, temperatures from differential temperature logs are on trend to BHTs. Color codes used in temperature and geothermal gradient maps (figs. 10-11) are shown at the base of the graphs. 
A. Geothermal Gradients (from Well-Log BHTs) for Top Mississippian Strata vs. Depth (Sea-Level Datum)

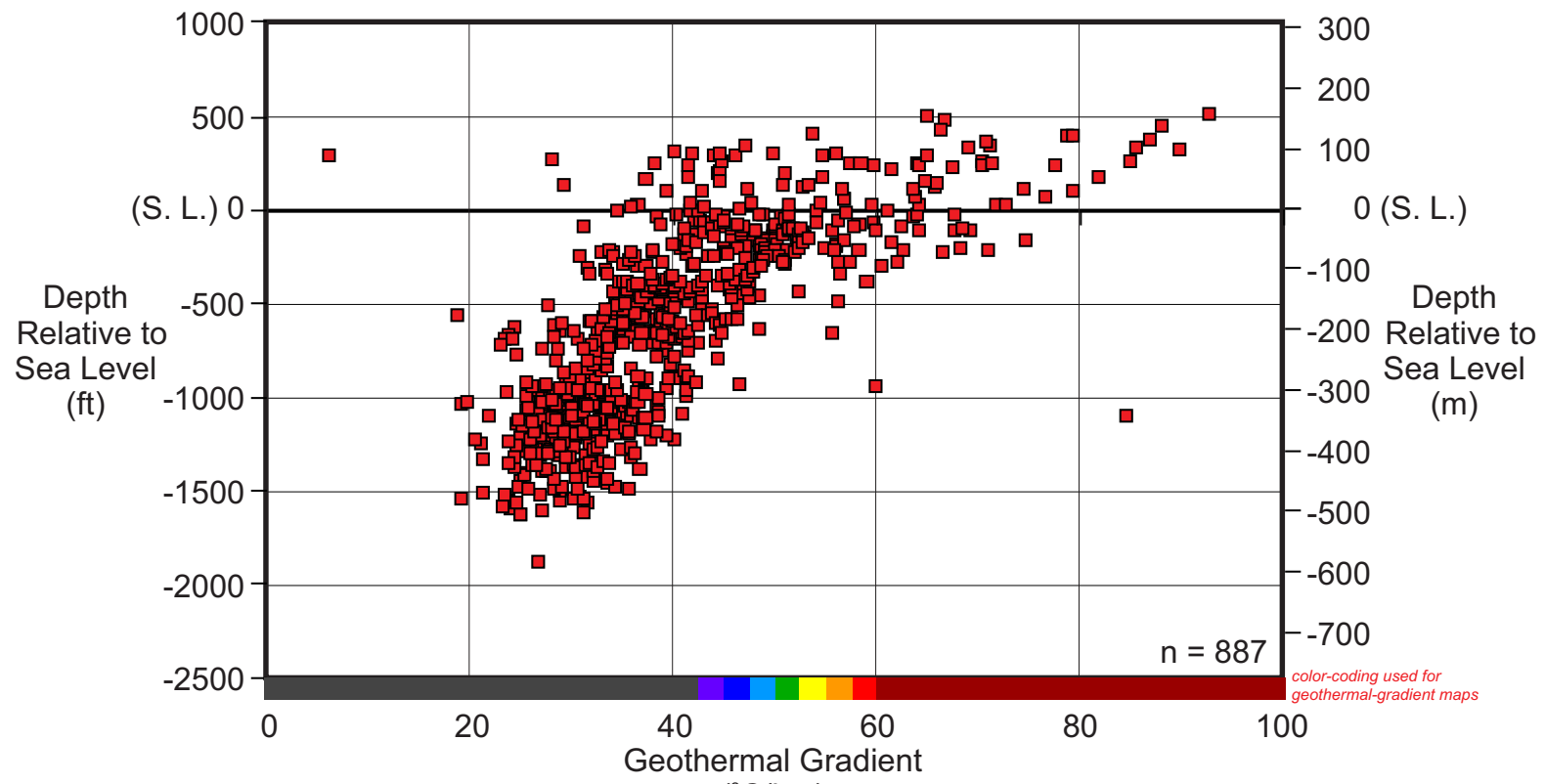

$\left({ }^{\circ} \mathrm{C} / \mathrm{km}\right)$

represents averaged geothermal gradient and averaged depth (relative to sea level)

determined from all well-logged bottomhole temperatures in a section (each section is approx. 1 by 1 miles [ 1.61 by $1.61 \mathrm{~km}]$ )

B. Geothermal Gradients (from Differential Temperature Logs) for Top Mississippian Strata vs. Depth (Sea-Level Datum)

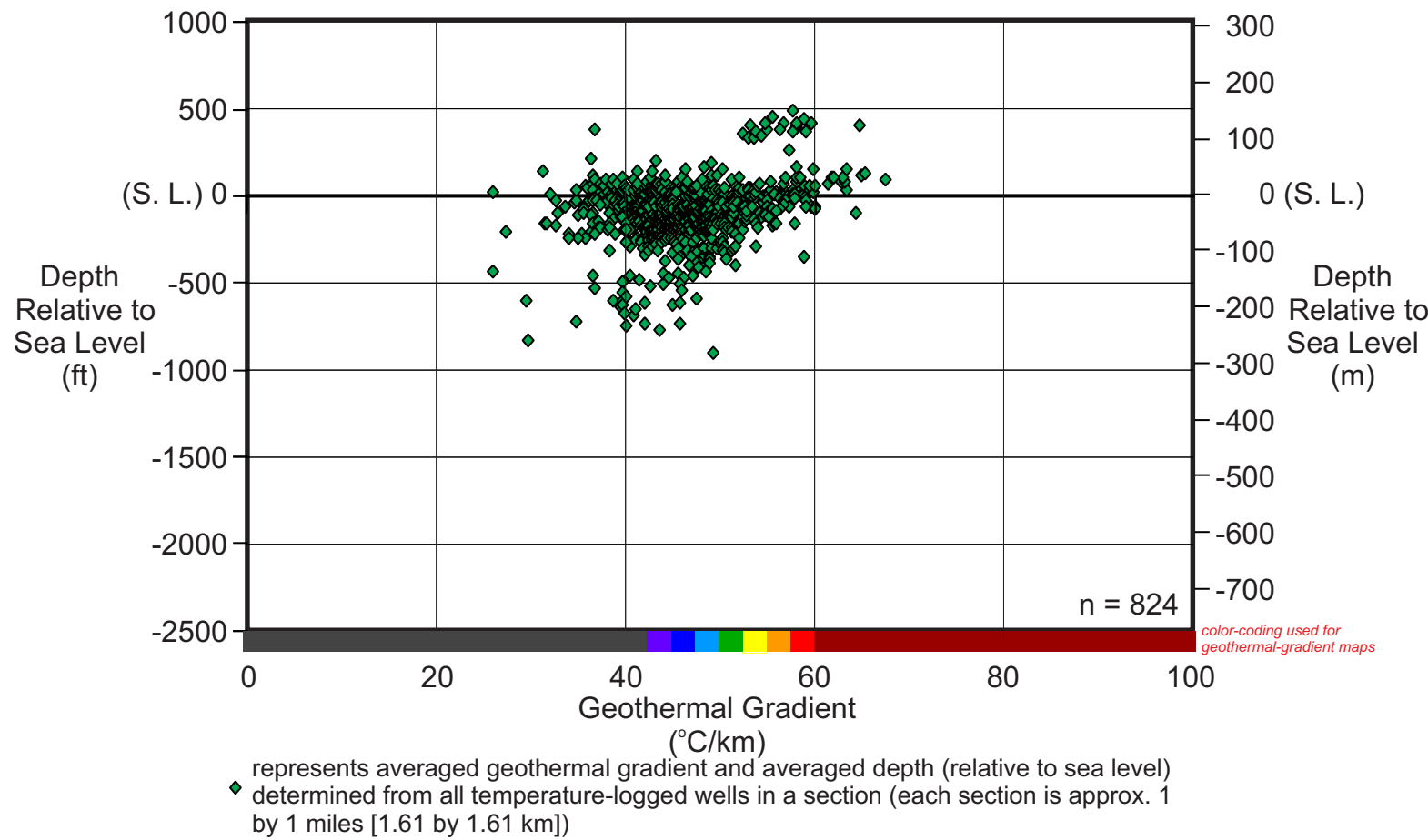

Figure 7. Comparison of geothermal gradients at the top of the Mississippian from (A) TDs and BHTs on log headers vs. (B) the depth of maximum temperature in Mississippian strata from differential temperature logs. Each symbol represents the depths and geothermal gradients averaged in one section. Although shallower, geothermal gradients from differential temperature logs are on trend to geothermal gradients derived from BHTs. Color codes used in temperature and geothermal gradient maps (figs. 10-11) are shown at the base of the graphs. 


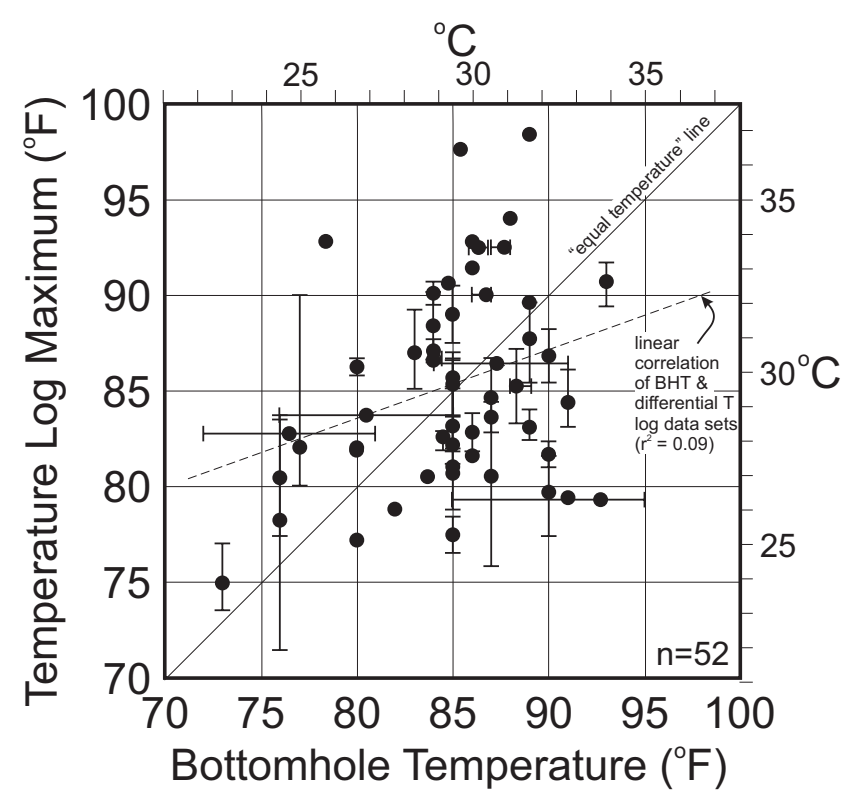

Figure 8. Cross-correlation of temperatures in Mississippian strata from BHTs obtained from log headers vs. temperatures read from differential temperature logs. Range and average temperatures are from those sections in which both types of temperature sources are available.

gradients changed abruptly over short distances. The high geothermal gradients in southeastern Kansas were also shown to gradually decrease westward to central Kansas, where gradients of 25 to $30^{\circ} \mathrm{C} / \mathrm{km}$ dominated. Studies of subsurface temperatures in Oklahoma (see Harrison et al., 1983) indicate that northeastern Oklahoma has elevated and abrupt laterally changing geothermal gradients similar to that of southeastern Kansas.

In this study, only temperature data for the top of the Mississippian strata in southeastern Kansas were considered and thus wells that were drilled either shallower or deeper than the Mississippian were not considered. BHTs and temperatures derived from the temperature logs were averaged on a section-by-section basis (each section is normally 1 sq. mi. [1.61 sq. km]). In the heavily drilled CBM fairways of eastern Kansas, four to eight wells per section may have temperature data. Results were mapped, with each section on the map color-coded according to its average temperature.

Surface temperatures used to calculate geothermal gradients were taken from a 30-year-average temperature map for the state (Kansas State University, 2000; fig. 9). Surface temperatures in the study area in southeastern Kansas varied from $53.9^{\circ} \mathrm{F}$ to $57.4^{\circ} \mathrm{F}\left(12.2^{\circ} \mathrm{C}\right.$ to $\left.14.1^{\circ} \mathrm{C}\right)$.

The resulting temperature map (fig. 10) and geothermalgradient map (fig. 11) are the main products of this study and the basis for identifying the thermal anomalies that are manifest on the broad, shallow-dipping eastern flank of the Cherokee basin. Virtually all subsurface temperature data from oil and gas drilling are recorded using U.S. customary units; hence, the subsurface temperature map (fig. 10) is presented in degrees Fahrenheit. However, the derivative maps and diagrams illustrating geothermal gradients are presented using the International Metric System (i.e., ${ }^{\circ} \mathrm{C} /$ $\mathrm{km}$ ) because most studies in subsurface heat flow and thermal gradients use this latter system.

The highest temperatures, about $120^{\circ} \mathrm{F}\left(49^{\circ} \mathrm{C}\right)$ were encountered along the axis of the Cherokee basin. Thermal anomalies of locally elevated temperatures on the eastern flank of the basin are isolated from the high temperatures present in the axis of the basin (i.e., areas of lower temperature separate the anomalies from the high temperatures along the basin axis). In regions away from areas densely drilled for CBM, other thermal anomalies are also evident, but their extent is unclear with presently available data.

\section{GEOTHERMAL GRADIENTS IN UPPER MISSISSIPPIAN STRATA}

Several areas displaying geothermal gradients greater than $50{ }^{\circ} \mathrm{C} / \mathrm{km}$ are present on the eastern flank of the Cherokee basin (fig. 11). These areas of high geothermal gradient generally correspond to areas of higher subsurface temperature (fig. 10). The highest temperatures, about $120^{\circ} \mathrm{F}\left(49^{\circ} \mathrm{C}\right)$, are along the axis of the Cherokee basin where the Mississippian strata are most deeply buried, but due to the depth, the resultant geothermal gradients are not commensurately high (i.e., $25-35{ }^{\circ} \mathrm{C} / \mathrm{km}$ ). Overall, geothermal gradients thus decrease farther westward deeper into the Cherokee basin. Earlier mapping of geothermal gradients by Stavnes (1982) also showed these areas of high geothermal

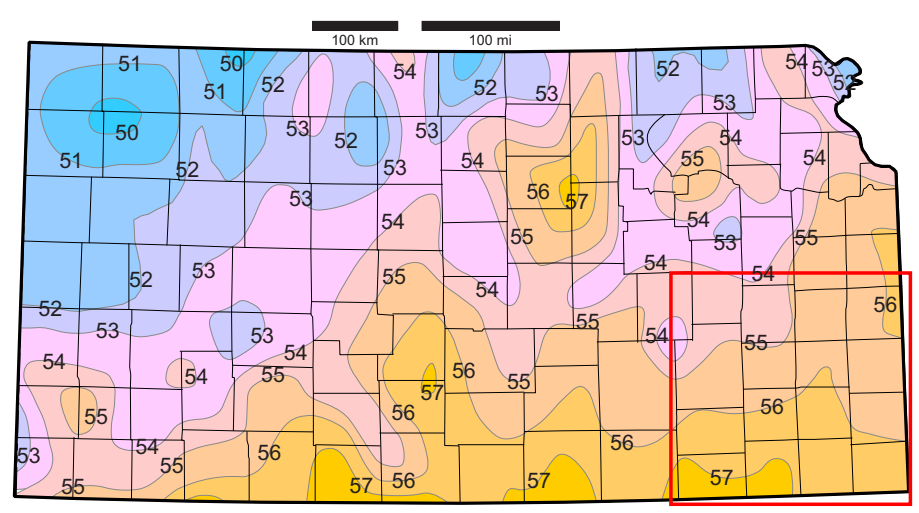

Figure 9. Kansas surface temperatures used in calculation of geothermal gradients (Kansas State University, 2000). The temperature range for the study area is $53.9^{\circ} \mathrm{F}$ to $57.4^{\circ} \mathrm{F}\left(12.2^{\circ} \mathrm{C}\right.$ to $\left.14.1^{\circ} \mathrm{C}\right)$. 
gradients in the eastern Cherokee basin. These geothermal gradients decrease westward to approximately $25-35^{\circ} \mathrm{C} /$ $\mathrm{km}$ in central and western Kansas.

Thermal anomalies identified on the temperature and geothermal-gradient maps (figs. 10-11) are named for the nearest town (see fig. 12). The largest of the anomalies the Mound Valley anomaly (A on fig. 12) - covers several townships. Two anomalies in extreme eastern Kansas the Hiattville and Devon anomalies — are problematic in that they are developed where the top of the Mississippian is at 150 to $500 \mathrm{ft}$ ( 46 to $152 \mathrm{~m}$ ) above sea level. This subsea depth interval translates to approximately 250 to $700 \mathrm{ft}$ (76 to $213 \mathrm{~m}$ ) below the surface, depending on surface elevations. At these shallow depths, subsurface temperatures can be artificially elevated due to warming from circulating drilling mud or even summer heat (see discussion above). Such artificially elevated subsurface temperatures are evident in the depth trend of BHTs in fig. $6 \mathrm{a}$, where the overall depth trend to temperatures projects to $70-80^{\circ} \mathrm{F}\left(21-27^{\circ} \mathrm{C}\right)$ at the surface. Carr et al. (2005) performed linear regressions on Mississippian and Arbuckle BHT data that were cross-plotted with bottomhole depths (i.e., TDs) for wells throughout Kansas. Their regressions produced an "uncorrected" surface intercept (with the intercept not forced to any specific surface temperature) of $79^{\circ} \mathrm{F}\left(26^{\circ} \mathrm{C}\right)$. A similar trend is evident for southeastern Kansas BHTs (see fig. 6a). Notably, temperatures derived from the differential temperature

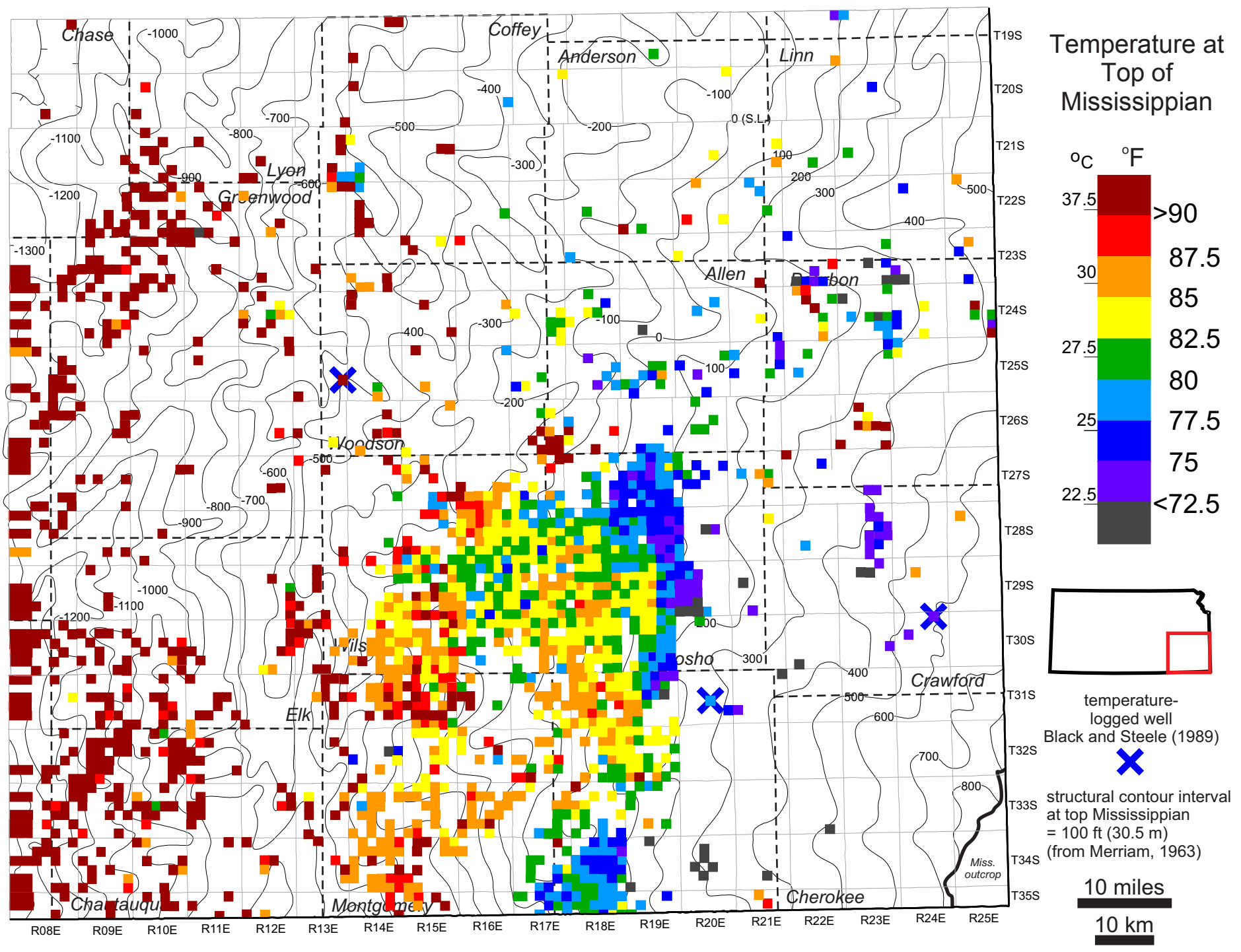

Figure 10. Temperature map for the top of the Mississippian, southeastern Kansas. BHTs from wells drilled into the top of the Mississippian and maximum temperatures (in ${ }^{\circ} \mathrm{F}$ ) in Mississippian strata from differential temperature logs were averaged for each section (i.e., nominally 1 by 1 mile [ 1.61 by $1.61 \mathrm{~km}]$ ) and colored-coded for each section. A structural contour map of the top Mississippian (after Merriam, 1963) underlays this map. 


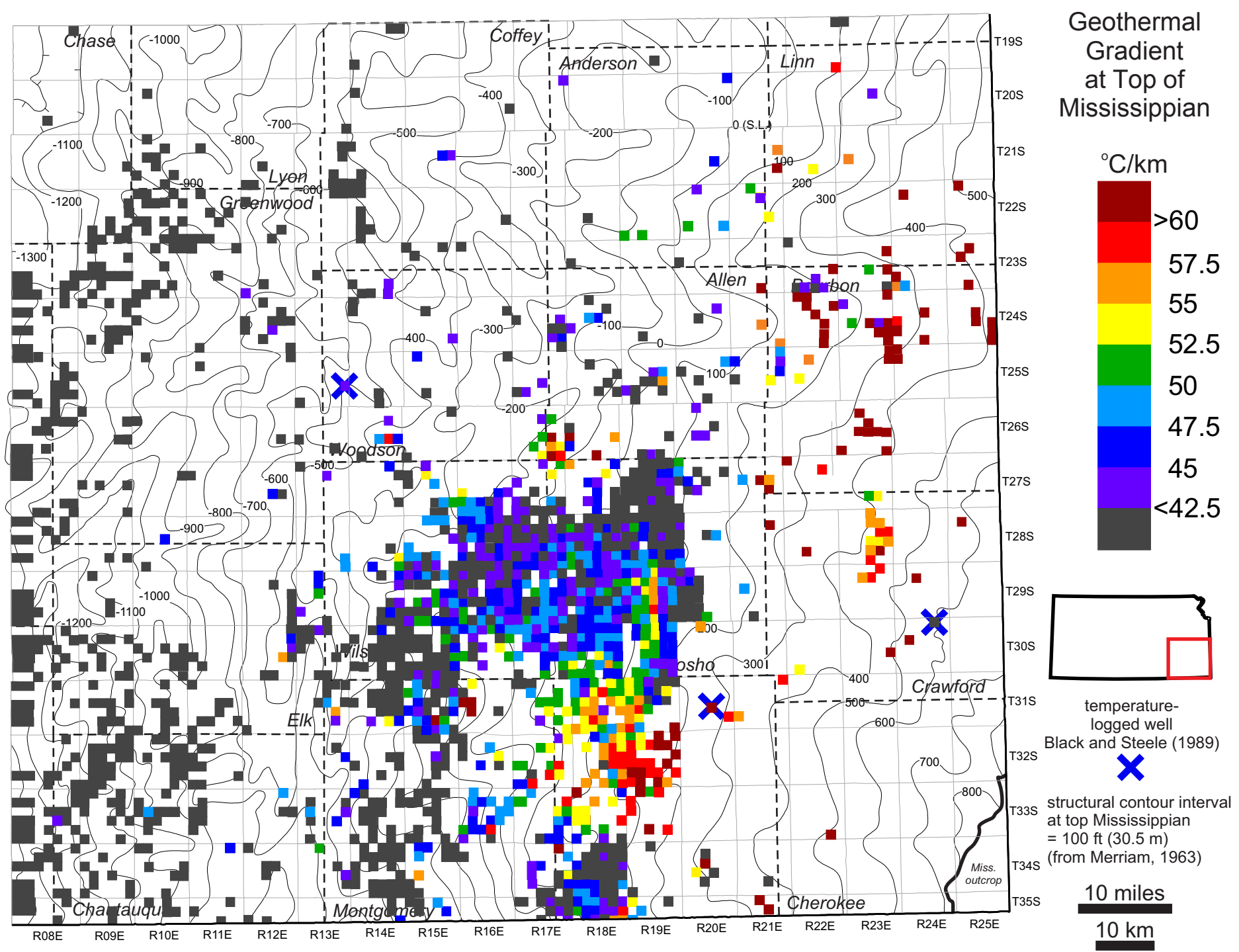

Figure 11. Geothermal gradient map for the top of the Mississippian, southeastern Kansas. Original measurements, taken in degrees Fahrenheit and feet, were converted to metric units. Geothermal gradients determined for each well were then averaged for all wells within each section (i.e., nominally 1 by 1 mile [1.61 by $1.61 \mathrm{~km}]$ ), then color-coded. A structural contour map of the top Mississippian (after Merriam, 1963) underlays this map.

logs (fig. 6b) project more closely to actual mean annual surface temperature (about $55^{\circ} \mathrm{F}\left[13^{\circ} \mathrm{C}\right]$ ), indicating that air-drilled wells may be less susceptible to wellbore heating, at least if these wells are not drilled during the heat of summer (see discussion above).

Comparison of the present-day thermal anomalies presented in this paper (see fig. 12) with thermal anomalies detected in Pennsylvanian strata by mapping vitrinite reflectance measurements (see Barker et al., 1992; Walton et al., 1995) shows that thermal conditions in southeastern Kansas have changed over geologic time. This is no doubt in response to the changing tectonic forces and the resultant changes in the direction of subsurface water movement.
The Mound Valley and Galesburg anomalies (fig. 12) will be examined in detail in the Discussion section of this paper. The Mound Valley anomaly is defined by numerous closely drilled differential temperature logs. This anomaly lies athwart several Mississippian structural contours (see figs. 10-11). Essentially, this means that the thermal anomaly is not an artifact of geologic structure, where the crestal areas of the structure are at shallower depths (at lower temperature) and the deeper parts thus lie in hotter environments.

The Galesburg anomaly is smaller than the Mound Valley anomaly, but it has an abrupt, north-south trending eastern margin beyond which temperatures and geothermal gradients decline abruptly. This anomaly is intensely drilled 


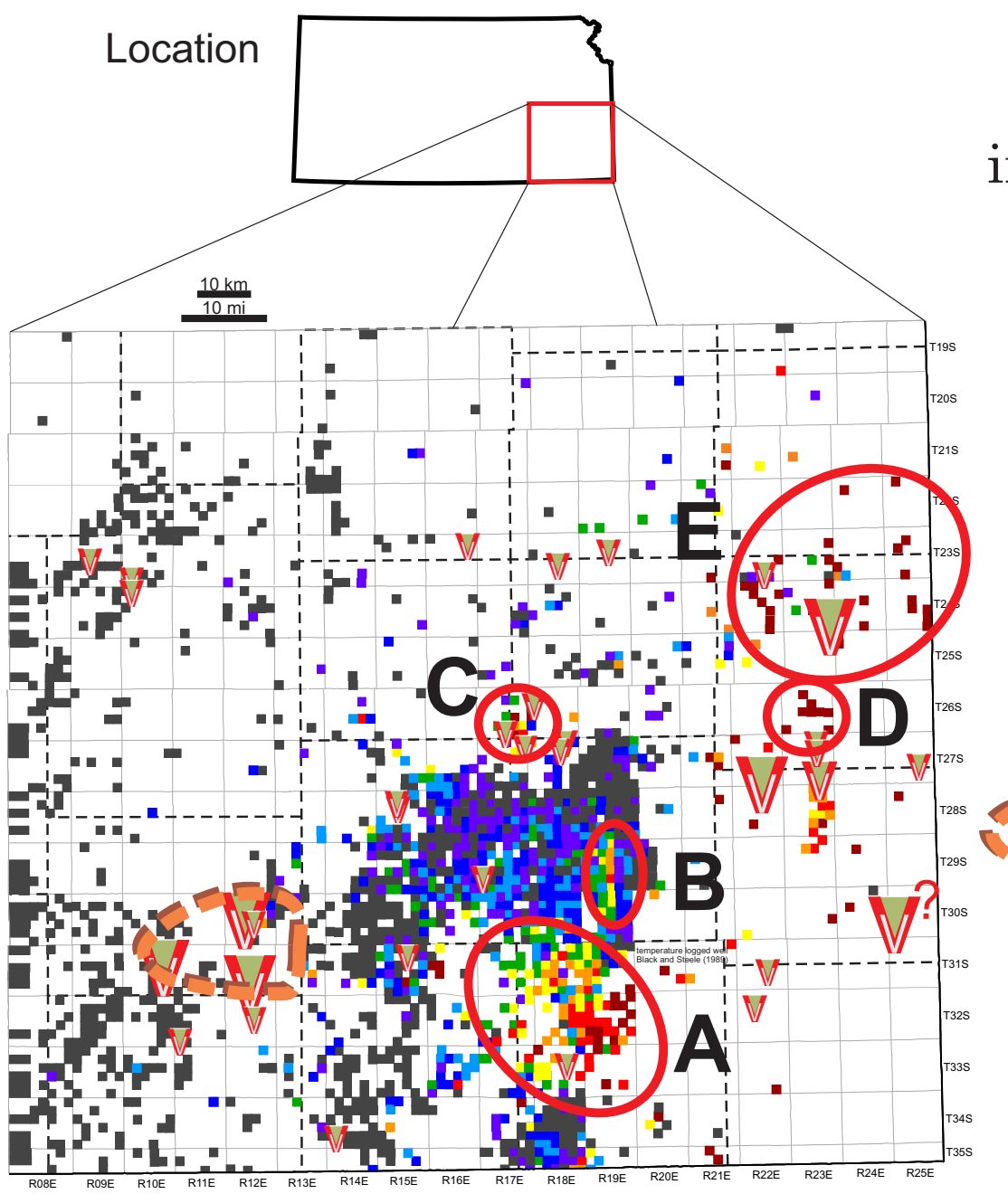

\section{Mississippian-Level Thermal Anomalies in Southeastern Kansas}

\section{A. Mound Valley B. Galesburg C. Petrolia D. Hiattville E. Devon}

Pennsylvanian (Desmoinesian) Cherokee Group vitrinite reflectance (Ro) measurements

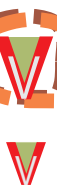

1.06-1.36 Ro; dashed orange line defines

"warm spot" from Walton et al. (1995)

V

0.80-1.05 Ro

V $\quad 0.52-0.79$ Ro

(vitrinite reflectance measurements from Barker et al., 1992; Foerster et al., 1998; Tedesco, 2021; Walton et al.,1995)

Figure 12. Thermal anomalies interpreted from the maps for temperature and geothermal gradient (figs. 10-11). The anomalies are named for the towns nearest to them. A "warm spot" (defined by dashed orange line), defined by vitrinite reflectance measurements in the overlying Pennsylvanian Cherokee Group, is one of two mapped in the Cherokee basin by Walton et al. (1995). Their western "warm spot," however, is west of the study area, and therefore off of the map, near the axis of the Cherokee basin near the Oklahoma state line. Sections are color-coded for geothermal gradient, from fig. 11. Vitrinite reflectance data are from Barker et al. (1992), Walton et al. (1995), Foerster et al. (1998), Tedesco (2021), and unpublished analyses compiled by the primary author.

for CBM, and the associated well logs will be examined to better understand a possible cause for these anomalies.

\section{DISCUSSION}

Ultimate confirmation or refutation of the thermal anomalies and their cause(s) probably has to wait for more detailed and closely spaced temperature logging of thermally equilibrated boreholes, as per research criteria recommended in Blackwell and Steele (1989). Blackwell and Steele (1989) note that vertical and lateral variations in temperature in the shallow crust primarily depend on three factors: heat production of basement rocks, the effects of lateral or vertical movement of subsurface water, and lithological variations that will affect thermal conductivity. Heat-flow variations that could account for the thermal anomalies defined in this paper are difficult to document, as basement tests for heat flow are sparse in this part of the midcontinent and basement lithologies are only generally known. Blackwell and Steele (1989) mention that only two wells in eastern Kansas tested for temperature and heat flow penetrate all the way to the basement. Neither well is in the study area, and only three of their shallower temperature-logged wells are in the study area (locations noted on figs. 10-11).

Examination of the thermal anomalies should be in the context of the relationship of the geothermal gradient to heat flow and thermal conductivity (see Selley, 1998, p. 156):

heat flow $=$ geothermal gradient $\mathrm{X}$ thermal conductivity of rock

Eq. 1 
Heat flow is in units $m \mathrm{~W} / \mathrm{m}^{2}$ (i.e.. milliwatts per square meter), geothermal gradient is in ${ }^{\circ} \mathrm{C} / \mathrm{km}$; thermal conductivity is in $\mathrm{W} /\left(\mathrm{m}^{\circ} \mathrm{C}\right)$ (where $\mathrm{W}=$ watts [note that $1,000$ milliwatts $=1 \mathrm{~W}], \mathrm{m}=$ meters, ${ }^{\circ} \mathrm{C}=$ degrees Celsius).

Given uniform thermal conductivity, a geothermal gradient should be proportional to heat flow, which, in turn, should be proportional to the radioactivity of the basement rocks (Roy et al., 1968). Conversely, rocks with greater thermal conductivity will inversely affect the geothermal gradient. In the context of depth, subsurface isotherms will bunch up beneath a rock layer with poor thermal conductivity. A jump in temperature and geothermal gradient will thus occur immediately downhole of the poorly conductive layer.

Thermal conductivity of sedimentary rocks can vary considerably (table 1).

Table 1. Rock types and their thermal conductivities (Selley, 1998, p. 156). Units are $W /\left(m{ }^{\circ} C\right)$ where $W=$ watts, $m=$ meters, ${ }^{\circ} \mathrm{C}=$ degrees Celsius

\begin{tabular}{cc}
\hline \hline Rock type & Thermal conductivity \\
\hline Halite, Anhydrite & 5.5 \\
Dolomite & 5.0 \\
Limestone & $2.8-3.5$ \\
Sandstone & $2.6-4.0$ \\
Shale & $1.5-2.9^{\star}$ \\
Coal & 0.3 \\
\hline
\end{tabular}

*Blackwell and Steele (1989) state thermal conductivity of midcontinent shale may be lower, on the order of 1.1.

Differences in porosity cause the range in thermal conductivities of sandstone, limestone, and shale because the thermal conductivity of pore water is lower than that of the mineral matrix (Selley, 1998, p. 156). Oil has a thermal conductivity about $1 / 5$ that of water, and natural gas is even lower at about $1 / 14$ that of water (Ball, 1982).

\section{Mound Valley Anomaly}

A north-south cross section, traced along the eastern margin of the R. 18 E. township tier (fig. 13), transects the Mound Valley anomaly. This cross section is almost parallel to structural strike in this part of the Cherokee basin; therefore, the tops of the units depicted in the structural cross section (fig. 13a) do not vary much in elevation. Average temperatures (fig. 13b) and average geothermal gradients (fig. 13c) determined for each section in the tier on the eastern margin of each township (specifically, from north to south, sections $1,12,13,24,25$, and 36 in each township) show considerable scatter in their average and range, but overall, both the temperature and geothermal gradient (as measured at the top of the Mississippian section) are elevated over the anomaly. There is no apparent correlation of these geothermal characteristics (fig. 13b-c) to geologic structure (fig. 13a), except that the anomaly abruptly terminates south of $\mathrm{T} .32 \mathrm{~S}$. The region comprising townships T. 33 S., T. 34 S., and T. 35 S. exhibits some folding and is a manifestation of a tectonic terrane called the Fall River Tectonic Zone (FRTZ) (Berendsen and Blair, 1986, 1991). The FRTZ is a broad northwest-southeast trending zone of inferred faulting and folding that extends into central Kansas. Strike-slip faults may be present, with periods of movement over Precambrian and Phanerozoic time.

Blackwell and Steele (1989) concluded that heat flow in southeastern Kansas does not drastically vary and that most variations in geothermal gradient are due to differences in thermal conductivity of the Phanerozoic strata. Specifically, they cite that the low thermal conductivity of Pennsylvanian strata has an insulating effect on underlying Mississippian strata, thus causing geothermal gradients based on temperatures measured within Mississippian drill holes to be higher than the gradients calculated for the overlying Pennsylvanian strata. Geothermal gradients based on temperatures measured in the well below the Mississippian are generally lower than those measured in the Mississippian.

As a test to determine whether lateral changes in thermal conductivity of Pennsylvanian strata can contribute to the Mound Valley anomaly, shale content in overlying Pennsylvanian strata was measured for logged wells along the trace of the cross section (fig. 13d). The measurement of shaliness in well logs and what cutoffs were used to determine shaliness were determined as follows. Doveton (2014, p. 47-48) stated that the average midcontinent gray shale has a reading of 120 API gammaray units, based on observation and calculations of gammaray summations for thorium, potassium, and uranium content in typical gray shales. The volume of shale $\left(\mathrm{V}_{\mathrm{sh}}\right)$ in a given stratigraphic unit can be expressed as follows:

$$
\mathrm{V}_{\mathrm{sh}}=(\mathrm{G}-\mathrm{C}) /(\mathrm{S}-\mathrm{C})
$$

where $G, C$, and $S$ are gamma-ray readings (usually in API gamma-ray units). Based on observation in southeastern Kansas well logs, a clean formation with no shale (C) is 15 API gamma-ray units; $100 \%$ shale (designated by the reading S) is 120 API gamma-ray units; and G is the reading at any given depth. Inasmuch as the gamma-ray value of a 


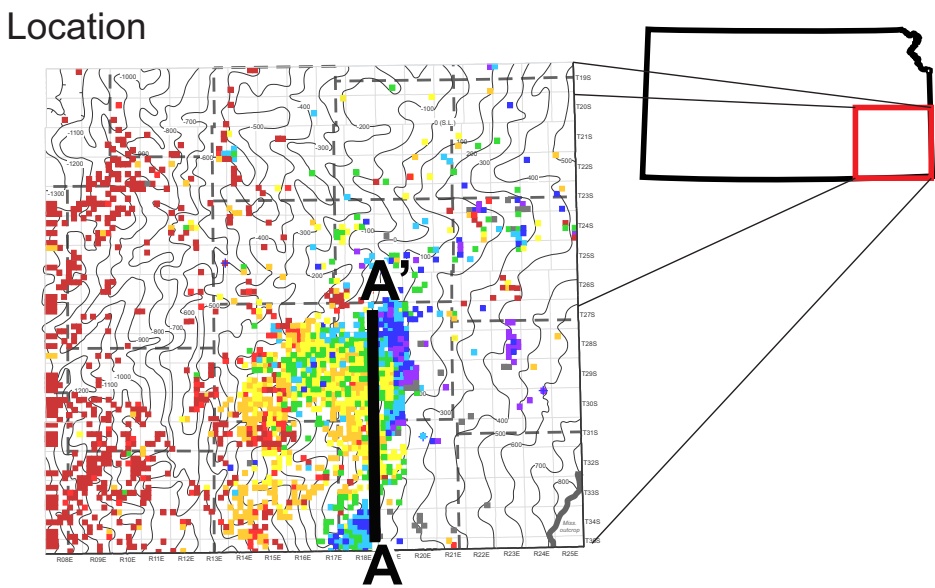

A
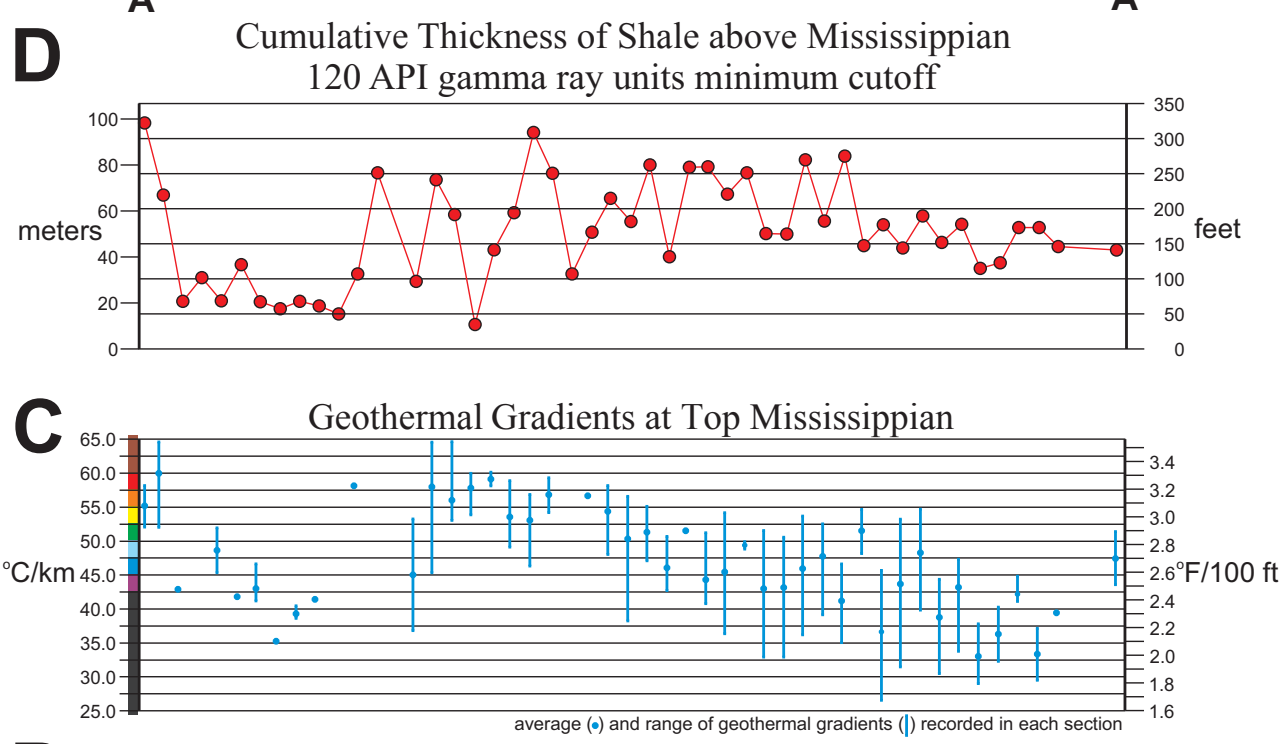

B
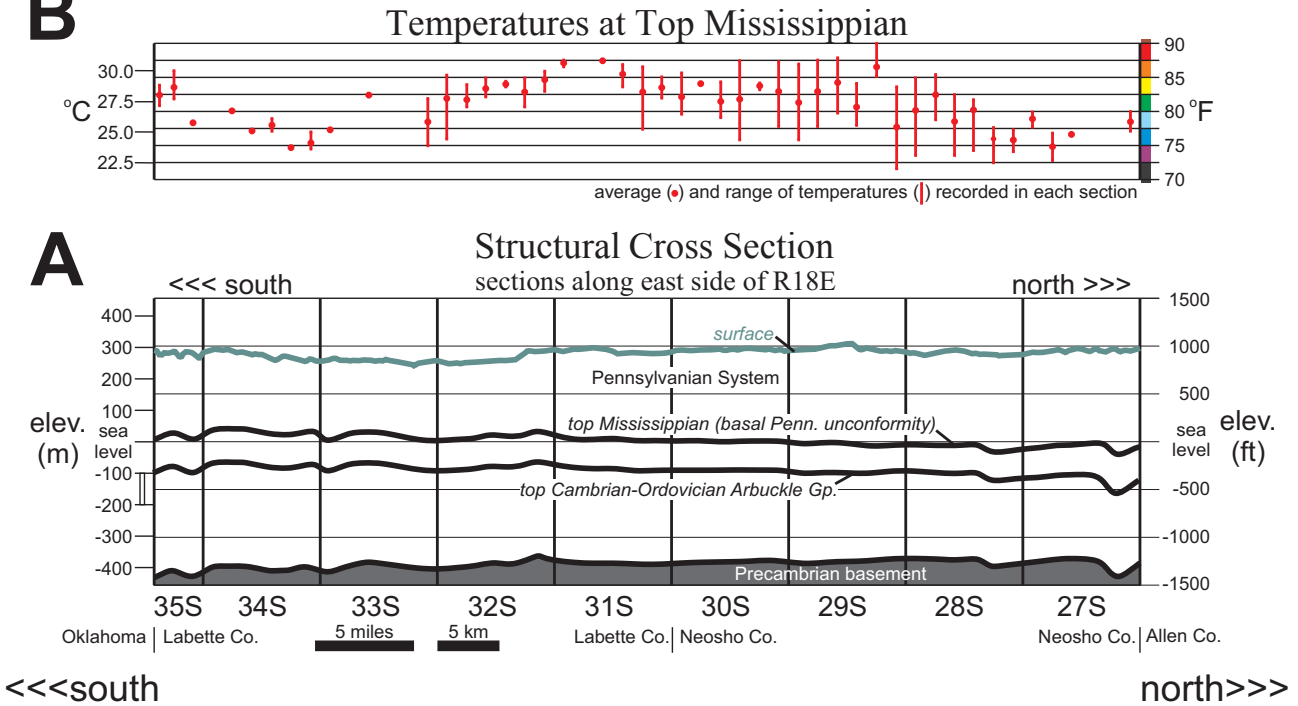

Figures 13. North-south cross section transecting the Mound Valley anomaly, summarizing structural and geothermal characteristics of sections along the east side of the R. 18 E. tier of townships. (A) Structural cross section, which is oriented almost along strike in this part of the Cherokee basin, (B) average temperatures and ranges recorded in Mississippian strata, (C) average geothermal gradient and ranges recorded in Mississippian strata, and (D) cumulative thickness of shale in Pennsylvanian strata that overlies the Mississippian. Sections on the index map are color-coded for temperature, according to the scale in fig. 10. Color codes of temperatures and geothermal gradients, respectively, used in figs. 10-11 are shown at the margins of the graphs in fig. 13b-c. Location map is the temperature map (fig. 10). 
pure shale (S) may vary with the geologic age of the shale and for every basin, and because thermal conductivity of midcontinent shales is not precisely known (Blackwell and Steele, 1989), the shaliness of the Pennsylvanian was determined using several measures: (1) total footage of shale in a well using 100 API gamma-ray units as a minimum cutoff for shale, (2) total footage of shale using 120 API gamma-ray units as a cutoff, (3) percentage of shale in the Pennsylvanian using 100 API gamma-ray units as a cutoff, and (4) percentage of shale in the Pennsylvanian using 120 API gamma-ray units as a cutoff. In addition, the thickness of the thickest shale in each section using the 100 and 120 API gamma-ray cutoffs was also measured. Of these measures, the best correlation of geothermal gradient vs. shaliness was measure 2, the total footage of shale using 120 API gamma-ray units as a cutoff (fig. 14).

Total shale footage in the Pennsylvanian (120 API gamma-ray units minimum cutoff) in a north-south transect over the Mound Valley anomaly is presented in fig. $13 \mathrm{~d}$. Total shale footage is thickest where the temperatures (fig. 13b) and geothermal gradients (fig. 13c) in the Mound Valley anomaly are highest (i.e., T. 29 S.-T. 32 S.). Shale footages significantly drop off in T. $32 \mathrm{~S}$. to T. $35 \mathrm{~S}$. (in the FRTZ), where the geothermal gradient also drops abruptly. Thermal conductivity of the overlying Pennsylvanian section thus appears to be a factor causing the Mound Valley anomaly. Variations in heat flow may also play a causative role. Specifically, the dropoff of the geothermal gradient (fig. 13c) north of T. $32 \mathrm{~S}$. is more drastic than the northward decrease of the cumulative thickness of shale in the Pennsylvanian (fig. 13d). This may indicate that a northward decrease in heat flow may augment the effects of the gradual northward decrease of shale content along the line of the cross section.

The effects of water movement, either vertically (convectively) across strata or laterally (advectively) along strata, also need to be investigated. Unfortunately, there is no network of monitoring wells that continuously measures salinity, pressure, and static fluid levels (SFLs) in the Mississippian and Arbuckle in the study area, but regional studies of subsurface water movement in Kansas show that there is a general eastward movement of saline brine in the Arbuckle Group through most of the state. This eastward-moving brine interfaces with a northwestward-moving flow of freshwater out of Missouri (fig. 15). This interface occurs in southeastern Kansas in roughly the same area where subsurface flow in the Mississippian strata and Arbuckle Group are considered to be similar where both units are part of the OP aquifer system. The Arbuckle and Mississippian aquifers that collectively compose the $\mathrm{OP}$ aquifer system become separate aquifers where the intervening Chattanooga Shale is well developed, thus impeding any upward or downward flow between these two units.

Insight into water movement in southeastern Kansas can be gleaned from available well data, namely SFLs taken during mechanical integrity tests (MITs) of saltwater disposal wells and salinity measurements on formation water taken from Mississippian limestones and CambrianOrdovician Arbuckle dolomites. MITs are mandated to be performed on oilfield saltwater disposal wells every five years in Kansas. One of the measurements taken in these tests in eastern Kansas is the SFL, which is the depth to which formation water rises in the well due to ambient formation pressure when the well is open to the surface (Dahlberg, 1982, p. 41). Data from MITs are archived with the Kansas Corporation Commission (KCC), which is the state regulatory agency that oversees such testing. Most saltwater disposal wells in this part of southeastern Kansas send their effluent into one of two stratigraphic units Mississippian limestones or carbonates of the CambrianOrdovician Arbuckle Group.

Comparison of the SFLs of nearby Mississippian and Arbuckle disposal wells may give insight into the internal pressure of these units and where differences in pressure could force movement within and between these two units, provided the water can somehow breach the impermeable Chattanooga Shale where it separates the two units and other non-porous units within the Mississippian and Arbuckle. Presumably, faults, fractures, and leaky wellbores could be conduits for such water movement.

If Arbuckle disposal wells have higher SFLs than nearby Mississippian disposal wells, it is conceivable that warmer water in the Arbuckle could force its way upward and thus create a thermal anomaly in the Mississippian limestones near the source of convection. Conversely, if Mississippian limestones have higher SFLs, then warmer Arbuckle water could not force its way into the Mississippian even if conduits for convection were available. Instead, due to its higher pressure and density, water in the Mississippian would force its way into the Arbuckle through any available conduits.

The author obtained SFLs for several Mississippian and Arbuckle disposal wells in the vicinity of the Galesburg and Mound Valley anomalies from the KCC Oil and Gas Division. Figure 16 shows the locations of these wells in relationship to the north-south line of sections transecting the Mound Valley anomaly and the group of sections 


\section{Coefficients of Determination $\left(\mathrm{r}^{2}\right)$}

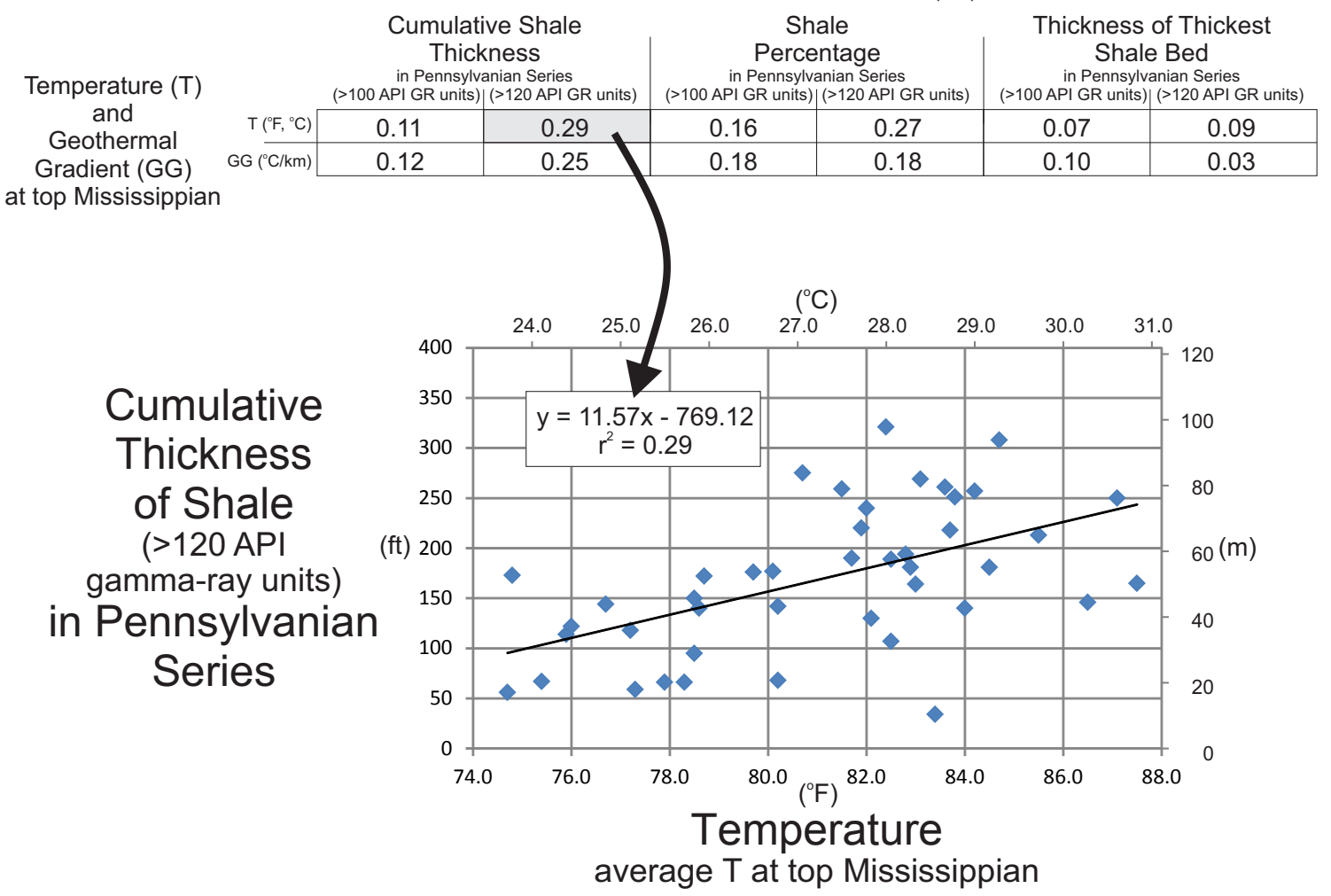

Figure 14. Average temperature and geothermal gradients of sections at top Mississippian level vs. thickness of shale in the overlying Pennsylvanian strata (east side of R. 18 E. tier of townships, Mound Valley anomaly). Positive correlations of temperatures and geothermal gradients with various measures of shale (i.e., total footage of shale, percentage of shale in strata, thickest shale using minimum gamma-ray cutoffs of 100 and 120 gamma-ray API units) are tested by cross-plotting average temperature and geothermal gradients with these shale parameters and then determining the coefficient of determination $\left(r^{2}\right)$. The best correlation $\left(r^{2}=0.29\right)$ is between temperature and total footage of shale using the 120 API gamma-ray unit cutoff. The cross-plot for this particular relationship is shown. The total footage of shale (120 API cutoff) is shown in fig. 13d.

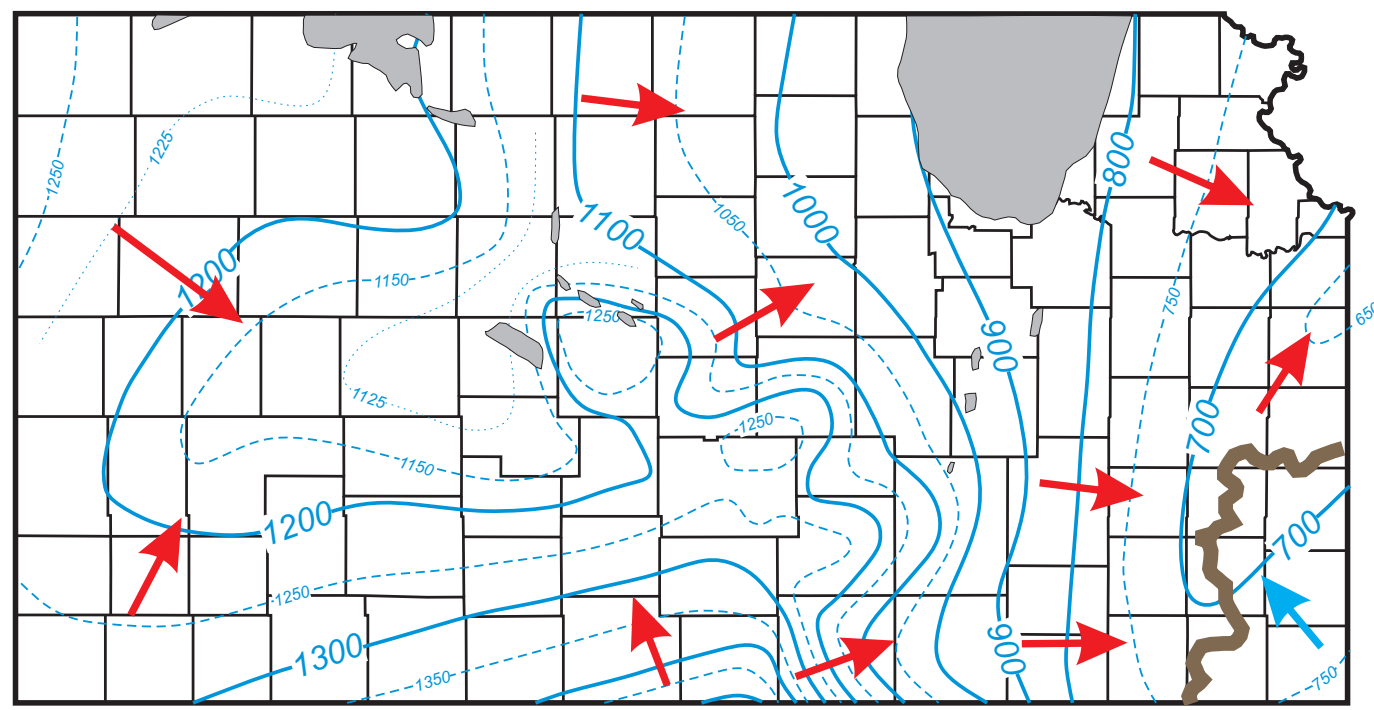

Figure 15. Potentiometric surface of the Arbuckle Group (freshwater equivalent density) showing direction of movement of subsurface fluids (after Newell et al., 2020). Contours are footage above sea level. Red arrows show the direction of movement of subsurface brine; blue arrow shows direction of movement of freshwater off the Ozark dome. Brown line (from Carr et al., 2005) is 10,000 ppm TDS, which essentially marks the boundary between freshwater and basinal brine. Gray areas are where the Arbuckle is absent due to erosion or non-deposition. 
covering the Galesburg anomaly (to be discussed later). Two graphs in fig. 16 show the SFLs for the disposal wells in adjacent 3-by-3 township blocks. Mississippian well D and Arbuckle well 7 are shown in both graphs because they are near both of the two nine-township blocks.

In general, SFL elevations for Mississippian disposal wells are at higher elevations than SFLs for Arbuckle disposal wells (fig. 16); therefore, upward movement of warmer Arbuckle water into the Mississippian caused by higher relative pressure in the Arbuckle is not a major cause of the Mound Valley anomaly. The converse is more likely in that higher relative pressures in the Mississippian will likely force Mississippian formation water into the Arbuckle if any faults or fractures perchance hydrologically connect the two formations. However, in both graphs, SFLs in one or more Arbuckle wells (see wells 7, 11, and 13) appear to be at higher elevations than nearby Mississippian disposal wells since 2007. This is a relatively recent phenomenon, which occurs after the drilling and temperature logging of the CBM wells on which this study is based, but it does show that SFLs and pressures in both units are changing with time.

Advective movement of formation water and its possible influence on the Mound Valley anomaly can be tested by looking at formation-water salinities. A possible scenario accounting for the thermal anomalies is that deep, highly saline basinal brines could have moved updip from the basin axis on to the relatively shallow eastern flank of the Cherokee basin. By this provisional model, if highly saline, hot brines were causing the thermal anomalies, then wherever high geothermal gradients are present, the Mississippian formation waters should also be very saline. Conversely, cooler areas farther updip and at the perimeter of the anomalies should be characterized by formation water with lower salinity. Furthermore, the warmer, highersalinity water accounting for the thermal anomaly should be traceable downdip toward the axis of the basin.

The Kansas Brine Database, which is available on the Kansas Geological Survey website (see Kansas Geological Survey, 2020b), is a primary source of salinity and chemistry of formation water. This online database reports chemical compositions of formation waters from various geologic units in terms of major cations $\left(\mathrm{Na}^{+}, \mathrm{Ca}^{++}, \mathrm{Mg}^{++}\right)$, anions $\left(\mathrm{Cl}^{-}, \mathrm{HCO}_{3}^{--}\right.$, and $\left.\mathrm{SO}_{4}^{--}\right)$, and as parts per million total dissolved solids (ppm TDS).

Salinity data for Mississippian rocks are sparse in eastern Kansas, so well-log analysis was used to supplement data from the Kansas Brine Database. The analytical technique used is the "reconnaissance water resistivity method" (Doveton, 2004). This method is widely used by log analysts to establish water resistivity from deep-resistivity and porosity wireline logs (Doveton, 2004). Typically, the resistivity measurement is from a deep induction log and the porosity measurement is derived from averaging the respective porosity measurements of the density and neutron logs. The apparent resistivity of the formation water (Rwa) is derived from the classic Archie Equation (Archie, 1942) and then adjusted from formation temperature to a set temperature of $75^{\circ} \mathrm{F}\left(29^{\circ} \mathrm{C}\right)$ using temperature-conversion equations and charts for relating resistivity of salt solutions at various temperatures to $\mathrm{NaCl}$ concentrations (see Schlumberger, 1988, p. 5; chart Gen-9). The conversion nomogram can also be bypassed by using an equation that converts the Rwa data directly to $\mathrm{NaCl}$-equivalent salinity. The conversion of Rwa to $\mathrm{NaCl}-$ equivalent salinity, given by Bateman and Konen (1977), is as follows:

$$
x=\left(3.362-\log \left(R w_{75}-0.0123\right)\right) / 0.955
$$

where ppm $\mathrm{NaCl}$ equivalent $=10^{\mathrm{x}} ; \mathrm{Rw}_{75}$ is the Rwa at $75^{\circ} \mathrm{F}$ $\left(29^{\circ} \mathrm{C}\right)$.

Rwa and salinity calculations are readily done with spreadsheets acting on LAS well-log files or simply by reading the values off the logs themselves. The optimal lithologic parameters for which Rwa-to-salinity calculations can be made, according to Doveton (2004), are in zones with sufficient porosity (greater than $5 \%$, but $8 \%$ is the cutoff used in this study) and minimal shaliness (less than 50 API gamma-ray units, or $\mathrm{V}_{\mathrm{sh}}$ less than $50 \%$ ); thus, any zone that is too tight or too shaly is eliminated from any calculation. Any salinity determinations within 2 feet above or below an eliminated measurement were also ignored in this study, to eliminate any "sideswipe" from the induction or porosity logs. In addition, no hydrocarbons (gas or oil) should be present in the pore space for the reconnaissance water resistivity method to work as intended (Doveton, 2004).

Mapped TDS data for Mississippian and Arbuckle formation water in southeastern Kansas (fig. 17) show an overall westward increase into the Cherokee basin, where formation water has in excess of 100,000 ppm TDS near the axis of the basin in western Chautauqua, Elk, and Greenwood counties. On the eastern flank of the basin, salinities decrease eastward to where analyses register less than 10,000 ppm TDS. Instead of showing very high salinity, Rwa analyses in the center of the Mound Valley anomaly are very low and on trend with the eastward salinity decrease defined by salinity data from nearby 
28S, 29S, 30S - 18E, 19E, 20E MISSISSIPPIAN

DISPOSAL WELLS

A Richard Oil Co. Austin-Rush \#1-SWD sec 11-T28S-R18E

B R\&B Oil

Kepley Farms \#10-SWD sec 20-T28S-R18E

C Joe \& Jeff Kephart Hudson \#4 sec 21-T28S-R20E

D Brecheisen \& Cook Kite \#1-SWD sec 32-T30S-R19E

ARBUCKLE

DISPOSAL WELLS

1 Richard T. Falkin Cooney \#1 sec 22-T28S-R20E

2 Quest Cherokee, LLC Strange SWD 'A' \#1-30 sec 30-T28S-R20E

3 John M. Magee Graham \#4-A sec 14-T30S-R18E

4 Quest Energy Service Bailey \#1-SWD sec 18-T30S-R18E

5 A.W. Brecheisen et al. Vogel \#3 sec 23-T30S-R19E

6 Kephart Gas Production Allen Kephart \#2-SWD sec 27-30S-R18E

31S, 32S, 33S - 17E, 18E, 19E

MISSISSIPPIAN

DISPOSAL WELLS

E Donna Lee Oil Co. Perry \#KDP-17 sec 25-T32S-R17E

F Natural Capital, LLC Taylor \#1 SWD sec 18-T33S-R17E

ARBUCKLE

DISPOSAL WELLS

7 KanMap Inc. O'Brien \#1-SWD sec 12-T31S-18E

8 Fastrak Energy, LLC Hy Grade \#D-3 sec 33-T31S-R18E

9 Double Eagle Resources, LLC Myers-Dixon \#1 SWD sec 27-T32S-R18E

10 Colt Energy, Inc. Gregory 'B' \#A-1 sec 35-T32S-R17E

11 Colt Energy, Inc. Larry Gregory \#5 sec 02-T33S-R17E

12 Entransco Energy, LLC Moon \#2 sec 11-T33S-R18E

13 Foster Gas Corp. John Seckman \#13 sec 07-T33S-18E

14 Admiral Bay (USA) Inc. Hess \#SWD-1 sec 24-T33S-18E
MISSISSIPPIAN \& ARBUCKLE STATIC FLUID LEVELS vs. TIME

9-township area (28S, 29S, 30S - 18E, 19E, 20E), Neosho County

YEAR

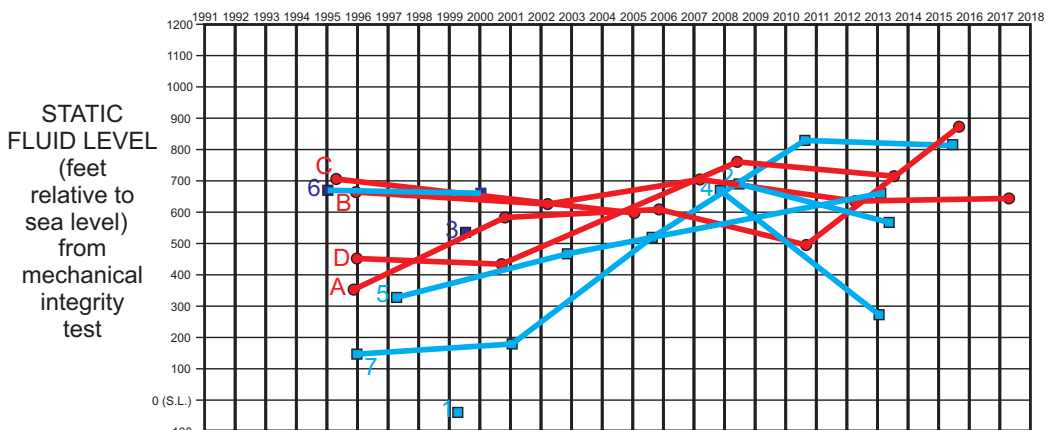

$\diamond^{26,312}$ Mound Valley Anomaly

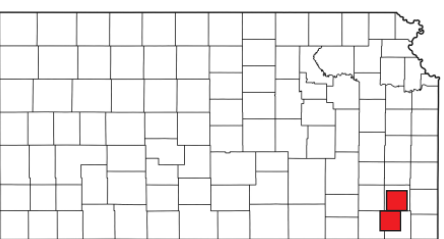

well disposing into Mississippian well disposing into Arbuckle
well with Mississippian brine analysis (ppm TDS) T30S well with Arbsippian brine analysis (ppm TDS

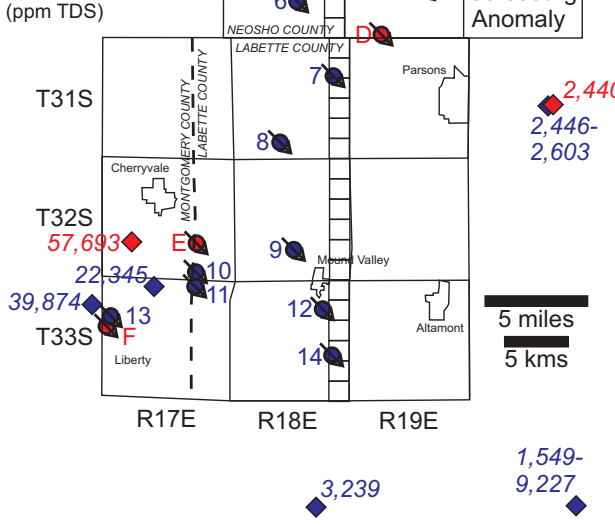

MISSISSIPPIAN \& ARBUCKLE STATIC FLUID LEVELS vs. TIME 9-township area (31S, 32S, 33S - 17E, 18E, 19E), Montgomery \& Labette Counties YEAR

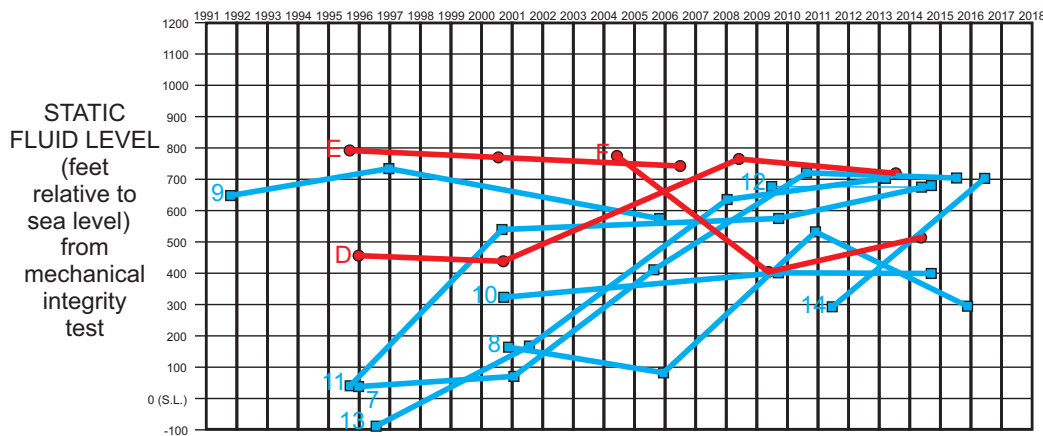

Figure 16. Disposal wells and static fluid levels in the vicinity of the Mound Valley and Galesburg anomalies. Two nine-township squares (each 18 by 18 miles [ 29 by $29 \mathrm{~km}$ ]), adjacent to each other, compose the map area. Diamond symbols show formationwater salinity in parts per million (ppm) total dissolved solids (TDS) from water samples taken from either the Mississippian limestones (red) or Arbuckle (blue) (from Kansas Geological Survey, 2020b). Mississippian disposal wells are lettered (in red); Arbuckle wells are numbered (in blue). Outlines show the north-south line of sections depicted in fig. 13 for the Mound Valley anomaly and the block of 36 sections used for mapping the Galesburg anomaly. See text for discussion. 
wells. This indicates that eastward movement of dense, hot brine from the basin axis toward the basin flank is not a likely explanation of the Mound Valley anomaly. Water movement by convection or advection is not a major influence, but rather lateral differences in thermal conductivity of the overlying Pennsylvanian strata, possibly in combination with slight changes in heat flow, appear to be a primary factor.

The Chattanooga Shale constitutes a substantial impermeable layer between the Arbuckle and the Mississippian and thus would impede upward movement of warmer, less saline (ergo less dense) water from the Arbuckle to the Mississippian except in areas where substantial faulting has created highly permeable pathways. The Chattanooga is absent from large areas in the southern part of the study area (shaded areas, fig. 17), but over much of this area the salinity of the Arbuckle likely exceeds that of the Mississippian; thus, there would be no relative buoyancy of less saline water in the Arbuckle to force upward movement of water into the Mississippian. West-central Chautauqua County in the southwestern part of the study area, where there is no Chattanooga and where the Arbuckle has a lower salinity than the Mississippian, may be an area prone to mixing of formation water between these two stratigraphic intervals. The limit of the Chattanooga Shale is only generally mapped (from Merriam, 1963), so it may be too generalized to account for specific localities within the study area.

Based on potentiometric data in the Arbuckle, fig. 18 presents a conceptualization of the merging of the flow fields (i.e., eastward moving saline water from western Kansas and westward movement of freshwater from the Ozark dome in Missouri). The mixing of these two flow fields results in a transition zone depicted by Carr et al. (2005) and presented in figs. 13 and 17. The presence of the transition zone is validated with the TDS data presented in fig. 17, which indicates that the formation waters become increasingly fresher in the eastward direction. Cross-stratigraphic movement of formation water would be expected where hydraulic confinement between the Arbuckle and the Mississippian is thin to absent (i.e., in areas where the intervening Chattanooga Shale is thin to absent). The mixing of the two flow fields, in addition to the lesser thermal conductivity of the overlying Pennsylvanian section, may be the cause of the cooler groundwater observed from the temperature logs in the southern end of the Mound Valley anomaly south of T. 32 S. (see fig. 13b).
Galesburg Anomaly

The Galesburg anomaly is smaller than the Mound Valley anomaly (fig. 12). It is north-south oriented, and temperatures and geothermal gradients drop off abruptly on its eastern side (figs. 10-11). An east-west structural cross section of well logs (fig. 19) across the anomaly shows that the three easternmost wells have markedly lower temperatures at comparable depths to the five wells to the west. The five western wells are thus part of the anomaly. Subsequent comparisons will refer to the wells on the anomaly as the "five western wells" and the wells off the anomaly as the "three eastern wells."

The three eastern wells are structurally higher than the five western wells. The temperature of Mississippian and Pennsylvanian strata drops drastically from the Quest Cherokee, LLC \#1-15 Joe D. Clevenger well to the Quest Cherokee, LLC \# 1 Beachner Brothers, Inc. well to the east (fig. 19). The steep dip component between these two wells, as compared to other well-to-well dip components in the cross section, implies that there may be faulting between them.

A structure map for the top of the Mississippian (fig. 20) requires drawing several contour lines between the \#1-15 Joe D. Clevenger well and the \#1 Beachner Brothers, Inc. well and nearby wells. Approximately $30 \mathrm{ft}(9.1 \mathrm{~m})$ of throw is indicated. Faulting, if present, appears to be discontinuous and perhaps en echelon, but generally oriented north-south. The structural contour map is drawn with a northeast-southwest structural grain. Superimposed on each well is a circle, which is color-coded by the geothermal gradient measured from the differential temperature log from that well. Cooler colors (gray, purple, light blue, dark blue, green) indicate lower geothermal gradients whereas warmer colors (yellow, orange, red, brown) indicate higher geothermal gradients. Over most of the map (fig. 20), the lower geothermal gradients are almost isolated to higher structural positions, similar to what is evident on the structural cross section (fig. 19), but farther north in sections 33 to 36 in township T. 28 S., wells with high geothermal gradients are at similar elevations to wells to the east that have lower geothermal gradients (cf., wells along the $70 \mathrm{ft}[21.3 \mathrm{~m}]$ elevation contour). Several wells along the western edge of the map area (fig. 20) show lower geothermal gradients (colored gray, purple, light blue, and dark blue), thereby defining the western limit of the Galesburg anomaly.

Thermal conductivity differences between the three eastern wells (all having relatively lower geothermal gradients) and the five western wells (having relatively 


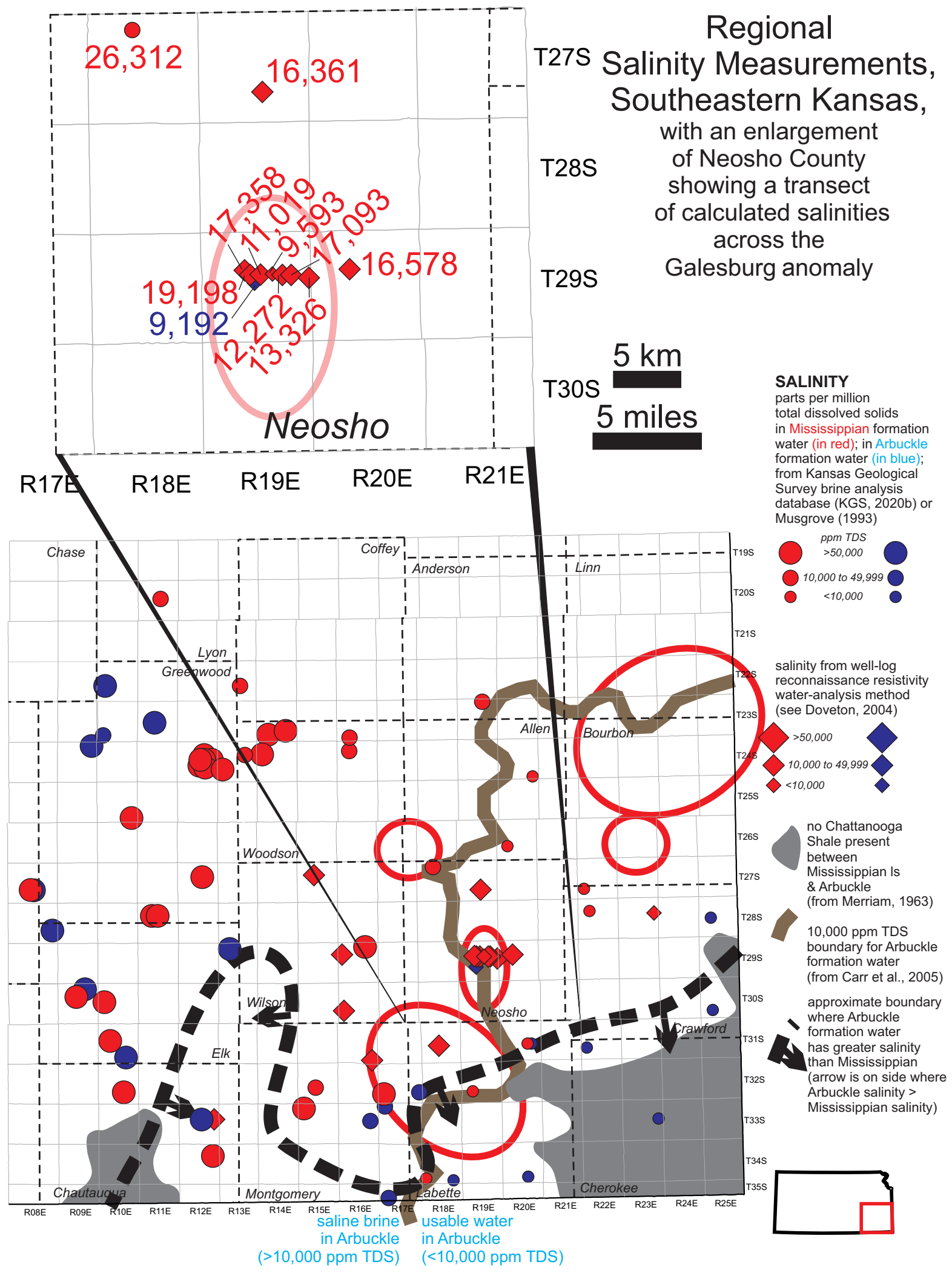

Figure 17. Salinity measurements (ppm TDS) for Mississippian and Arbuckle formation water taken from wells in the study area (from Kansas Geological Survey [2020b] and Musgrove [1993]). These data are supplemented by selected wells subjected to welllog determination of total dissolved solids by the reconnaissance water resistivity method (see text for discussion). The 10,000 ppm boundary line for Arbuckle formation water is from Carr et al. (2005). Arbuckle salinity (in blue) is less than that of the Mississippian (in red) over most of the study area, except for an ill-defined region in the southern part of the study area (see boundary line). Open red ovals indicate geothermal anomalies identified in fig. 12. 


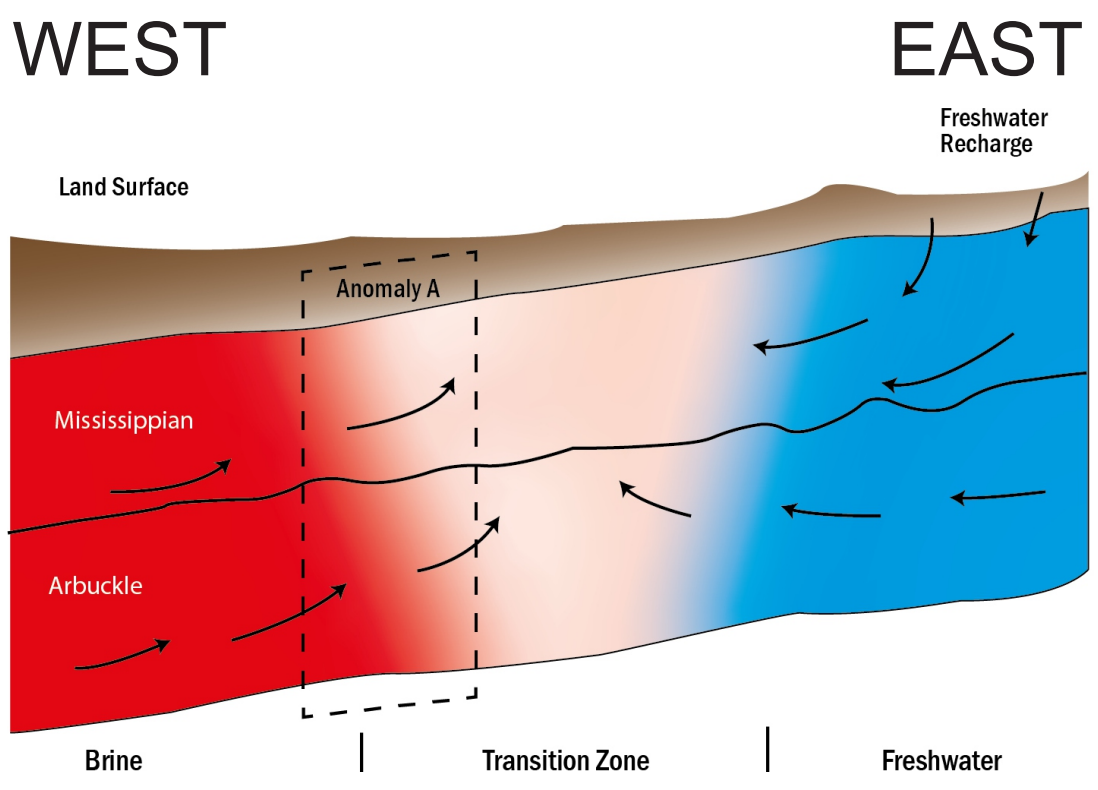

Figure 18. Conceptual cross section in southeastern Kansas where freshwater from the Ozark dome meets saline water from the west. Some of the water along the interface could be forced upward from the Arbuckle to the Mississippian, if lateral movement cannot completely move the waters at the interface down the potentiometric surface. Anomaly A could represent either the Mound Valley or Galesburg anomalies. The mixing of the two flow fields could also be the cause of the cooler groundwater observed from the temperature logs in the Mound Valley area south of T. 32 S. (see fig. 13b).

higher geothermal gradients) were tested by comparing the shale content in one of the five western wells and one of the three eastern wells. Shale content in the Pennsylvanian section above the Mississippian in the \#1-14 Jack L. Hines well (sec. 14, T. 29 S., R. 19 E.) and the \#16-2 Ronald D. Fowler well (sec. 16, T. 29 S., R. 19 E.; see fig. 19) indicated the Hines well has a collective thickness of $278 \mathrm{ft}(84.7 \mathrm{~m})$ of shale (using a 120 API gamma-ray unit cutoff) whereas the Fowler well has $248 \mathrm{ft}$ (75.6 m) of shale. Similarly, the Hines well also has greater shale content by the other measures employed (i.e., collective shale footage using a 100 API gamma-ray cutoff and percentages of shale within the Pennsylvanian with both the 120 and 100 API cutoffs). By these measures, the Pennsylvanian section in the Hines well should have lesser thermal conductivity and should cause a commensurately higher geothermal gradient at the Mississippian level than the Fowler well, provided heat flow is equal at the two wells. This is not the case, though, as the geothermal gradient is markedly lower at the Hines well (see fig. 19). This indicates the relatively high geothermal gradient at the Fowler well occurs despite the probable lower thermal conductivity of its Pennsylvanian section. The Galesburg anomaly must thus be caused by factors other than decreased thermal conductivity.

Salinity calculations (by the aforementioned reconnaissance water resistivity method) can give insight to movement of formation water and its effects on subsurface heat transfer. Calculated salinity measurements for the three eastern wells vs. the five western wells in the cross section in fig. 19 are presented in the two adjacent crossplots in fig. 21. Note that in this figure, salinities appear to rise with lower porosity. This is an artifact of well log analysis in that zones with lower porosity (less than $8 \%$ ) are due to the broad focus of the deep induction log, which does not always record an accurate measure for deep resistivity in thin resistive (i.e., non-porous) zones within and adjacent to the zones of its focus (see Asquith, 1982, p. 43). To minimize such effects, this study eliminated any salinity calculation from zones with less than $8 \%$ porosity or any calculation from a zone within 2 vertical feet $(0.65$ $\mathrm{m})$ of a zone with less than $8 \%$ porosity.

Significant eastward updip movement of hotter basinal water with higher salinity is not a likely cause of the Galesburg anomaly because overall, salinities in the five western wells are not drastically greater than in the three eastern wells (fig. 21). A detailed look at salinity of the wells along the cross section (fig. 19) by the reconnaissance water resistivity method shows slight differences in Mississippian formation-water salinity that run counter to the general eastward decrease in salinity seen in fig. 17. This localized drop in salinity may be significant. One of the wells, the Joe D. Clevenger \#1-15 well, registers an exceptionally low average salinity (i.e., 9,593 ppm TDS) and is between two wells with higher salinity (i.e., 11,019 and 12,272 ppm TDS). 


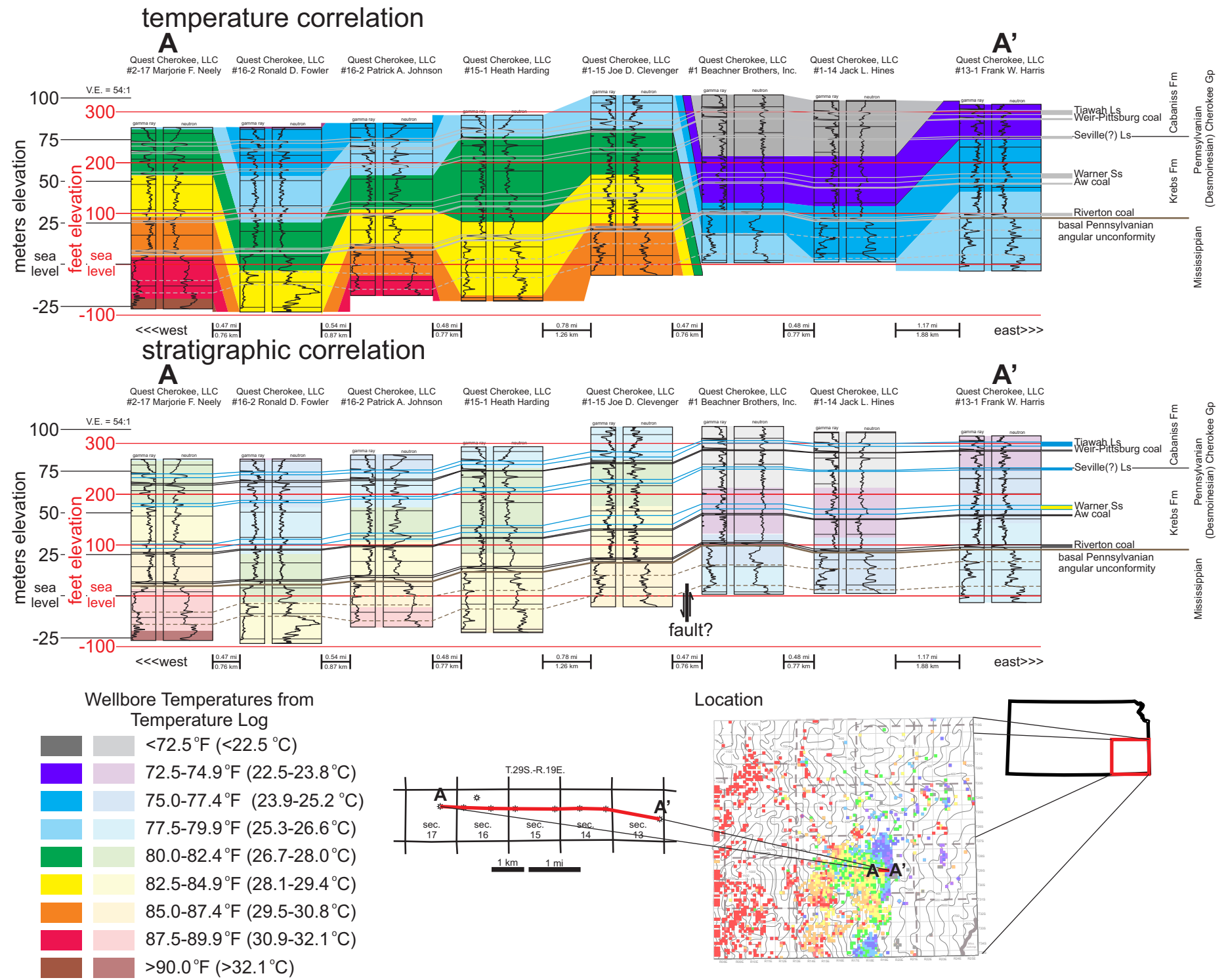

Figure 19. East-west structural cross sections across the Galesburg anomaly, extending from sections 13 to 17 , T. 29 S., R. 19 E. The three easternmost wells are off the eastern edge of the anomaly and the five westernmost wells are on the anomaly. Temperature intervals are color-coded and superimposed on the well logs in both cross sections. The two cross sections are essentially the same, except temperature intervals are brightened and stratigraphic correlations are faded in the upper cross section. Conversely, temperature intervals are faded and stratigraphic correlations are brightened in the lower cross section. The Galesburg anomaly is characterized by higher temperatures on the downside of steeply dipping (possibly faulted) strata west of the Beachner Brothers, Inc. \#1 well. The index map for the cross section is the subsurface temperature map (see fig. 10).

The \#1-15 Joe D. Clevenger \#1-15 well (the easternmost of the five western wells) is adjacent to the Beachner Brothers, Inc. \# 1 well, which is the westernmost of the three eastern wells that have the lower geothermal gradients. It is conceivable that the anomalously low salinities registered by the Joe D. Clevenger \#1-15 well and the nearby Heath Harding \#15-1 and Beachner Brothers, Inc. \#1 well could be caused by vertical convection of low salinity water from the underlying Arbuckle Group. The Arbuckle well nearest to the cross section is the Fowler SWD \#16-1 well (fig. 21).
This well has a calculated average salinity of 9,192 ppm TDS, which is lower than the overlying Mississippian wells and on par with that of the Joe D. Clevenger \#1-15 well.

Possible faulting on the eastern edge of the anomaly could serve as conduits for convection of formation water up from the Arbuckle. A temperature difference of about $10^{\circ} \mathrm{F}\left(76\right.$ to $86^{\circ} \mathrm{F}$ ) (about $5.6^{\circ} \mathrm{C} ; 24.4$ to $30^{\circ} \mathrm{C}$ ) occurs at the abrupt eastern margin of the Galesburg anomaly at the top of the Mississippian between the \#1-15 Joe D. Clevenger well and the Beachner Brothers. Inc. \#1 well (see fig. 19). 
GEOTHERMAL

GRADIENT at TOP MISSISSIPPIAN

based on temperatures and depths

from differential temperature log

at each well

$>60.0^{\circ} \mathrm{C} / \mathrm{km}$

$57.5-59.9^{\circ} \mathrm{C} / \mathrm{km}$

$52.5-54.9^{\circ} \mathrm{C} / \mathrm{km}$

$50.0-52.4^{\circ} \mathrm{C} / \mathrm{km}$

STRUCTURE CONTOURS at TOP MISSISSIPPIAN contour interval $=10 \mathrm{ft}$

${ }_{24}{ }^{\circ}$ well location, with top Mississippian elevation relative to sea level $55.0-57.4^{\circ} \mathrm{C} / \mathrm{km}$

$47.5-49.9^{\circ} \mathrm{C} / \mathrm{km}$

$42.5-44.9^{\circ} \mathrm{C} / \mathrm{km}$

$<42.5^{\circ} \mathrm{C} / \mathrm{km}$

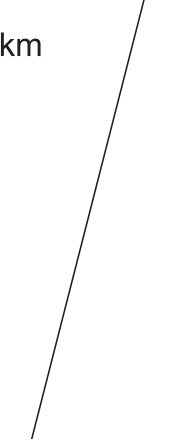

cross-section line, Figure 19

A. \#16-2 Ronald D. Fowler SW NE SW NW sec. 16-T29S-R19E B. \#16-2 Patrick A. John C. \#15-1 Heath Harding sw NW sec. 15-T29S-R19

D. \#1-15 Joe D. Clevenge NW SE SE NE sec. 15-T29S-R19E NW SE SE NW sec. 14-T29S R19E F. \#1-14 Jack L. Hines
NE SW SE NE sec. 14-T29S R19E NE SW SE NE sec. 14-T29S R19E

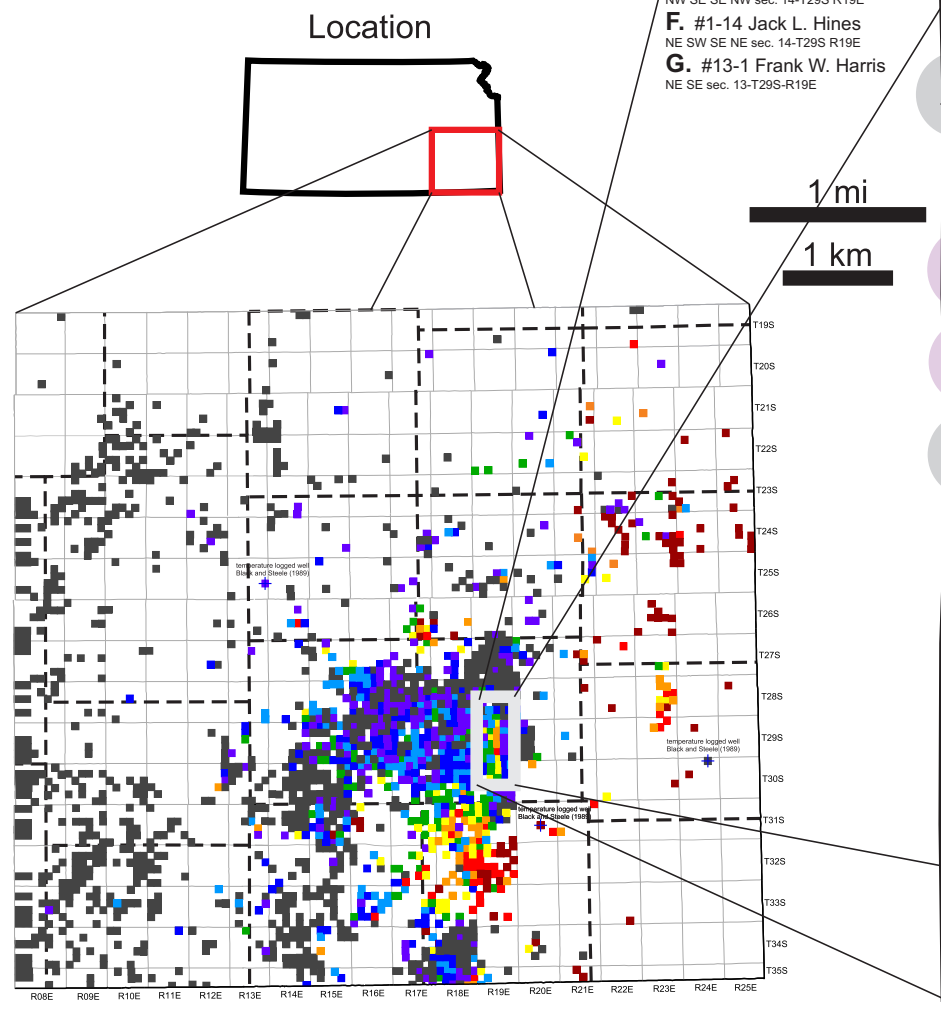

\section{8}

$19 \mathrm{E}$

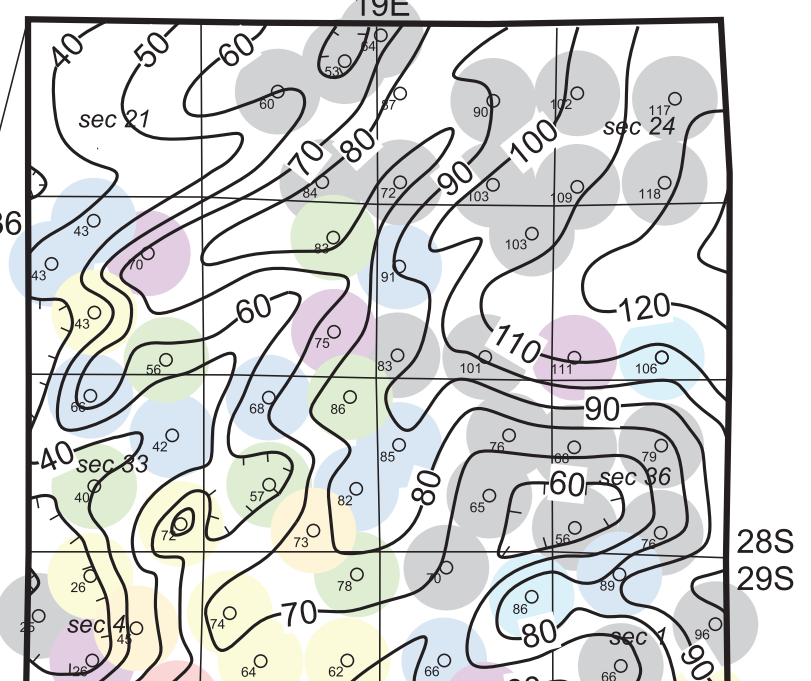

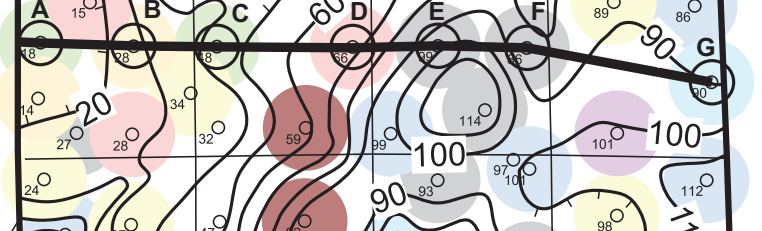
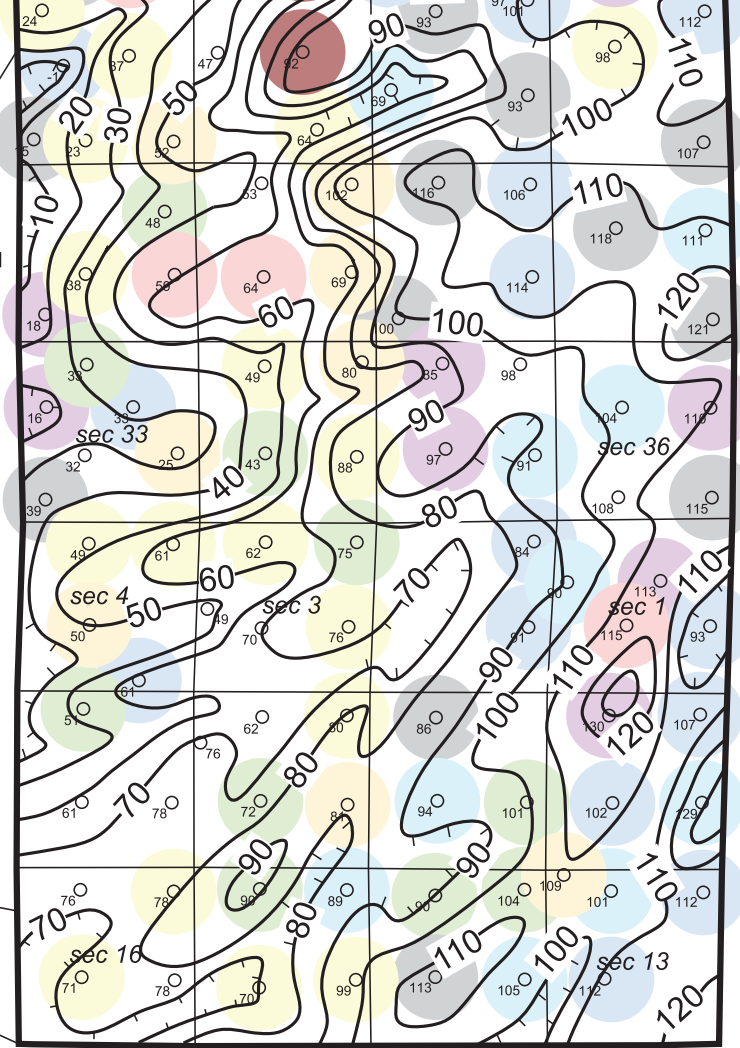

Figure 20. Structural map of the top of the Mississippian over the Galesburg anomaly. Some of the wells along the cross section in fig. 19 (excepting the westernmost well, in sec. 17) are noted. Geothermal gradients are noted by a color-coded circle around each well locality. These geothermal gradients were averaged for each section, and each section is color-coded on the regional geothermal gradient map (fig. 11) using the same levels of geothermal gradients as presented on this figure. 

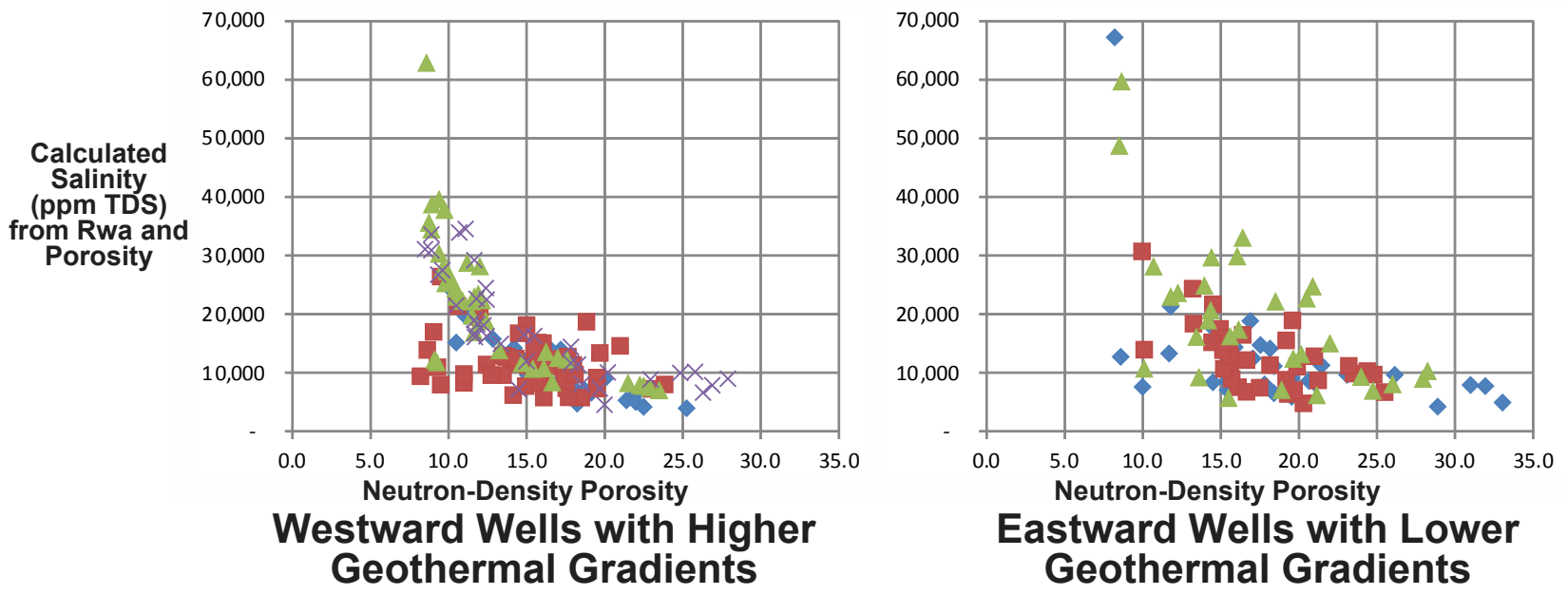

Joe D. Clevenger \#1-15
Heath Harding \#15-1
Patrick A. Johnson \#16-2
$\times$ Ronald D. Fowler \#16-1

Frank W. Harris \#13-1

- Beachner Bros., Inc. \#1

$\triangle$ Jack L. Hines \#1-14

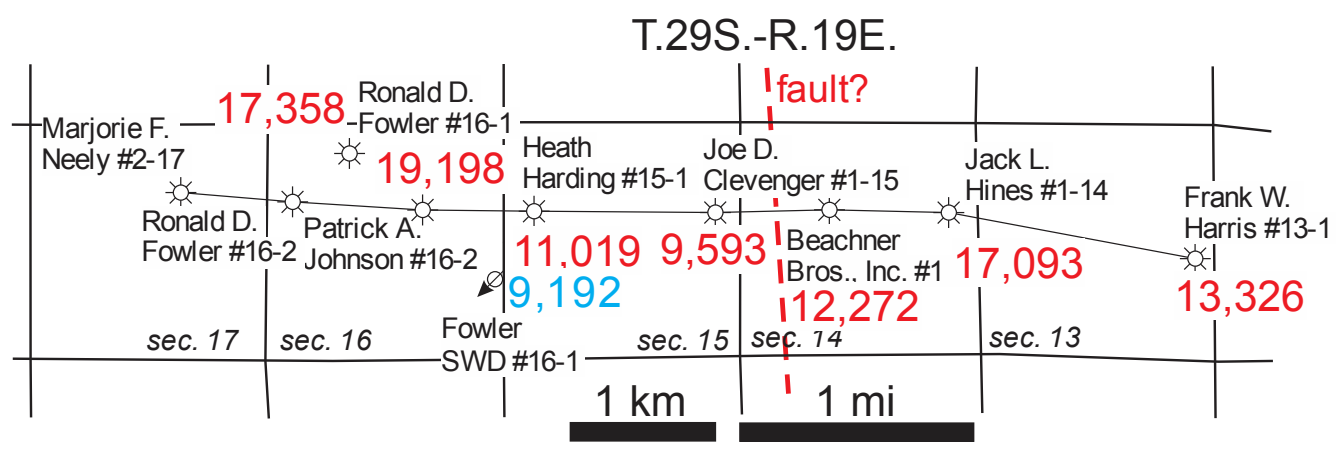

Figure 21. Cross-plots of salinity vs. porosity for, respectively, four western wells on the Galesburg anomaly and three eastern wells off the anomaly. These wells are along the structural cross section in figs. 19 and 20. The Ronald D. Fowler \#16-2 well was not used in salinity determinations because a dual induction log needed for these calculations was not available. Instead, the nearby Ronald D. Fowler \#16-1 well (1,430 ft [0.44 km] to the northeast) was used. See text for discussion. On the base map, average salinities are posted in red for each well penetrating the Mississippian section and in blue for wells in the Arbuckle. These salinities were determined by the reconnaissance water resistivity method and are summarized for each section and posted on the regional salinity map (fig. 17). The Arbuckle salinity at the Fowler SWD \#16-1, the nearest deep disposal well to the wells in the cross section, assayed a salinity (by the reconnaissance water resistivity method) that was less than any of the wells in the cross section.

This temperature difference corresponds to a difference in depth of about 670 to $950 \mathrm{ft}$ ( 200 to $290 \mathrm{~m}$ ), depending on geothermal gradient (i.e., 42.5 to $60{ }^{\circ} \mathrm{C} / \mathrm{km}$ is used in the calculations). This is roughly the difference in depth corresponding to the vertical distance between the top of the Mississippian and the middle to upper part of the underlying Arbuckle Group.

There are no Mississippian and Arbuckle disposal wells that are close to each other and centered within the Galesburg anomaly, but Mississippian well C and Arbuckle wells 1 and 2 are located near the north end of the anomaly, and Mississippian well D and Arbuckle well 5 are located near the south end of the anomaly (see fig. 16). However, SFLs indicate that the Mississippian has a higher pressure than the Arbuckle in both of these localities (fig. 16).

Comparison of shut-in pressures from drill-stem tests (DSTs) in southeastern Kansas (fig. 22) shows that pressure gradients for the Mississippian and Arbuckle are nearly identical when compared to the subsea depth of each unit (fig. 22a). However, the Arbuckle appears to have a slightly higher gradient when the pressures of each unit are plotted according to their subsurface depth (fig. 22a). These two units can be separated vertically by up to $800 \mathrm{ft}(244 \mathrm{~m})$ of strata in the northwestern corner of the study area and less than $200 \mathrm{ft}(61 \mathrm{~m})$ in isolated localities in the central part of the study area (fig. 22b). The thickness of the intervening strata (top-Mississippian to top-Arbuckle) in the vicinity 

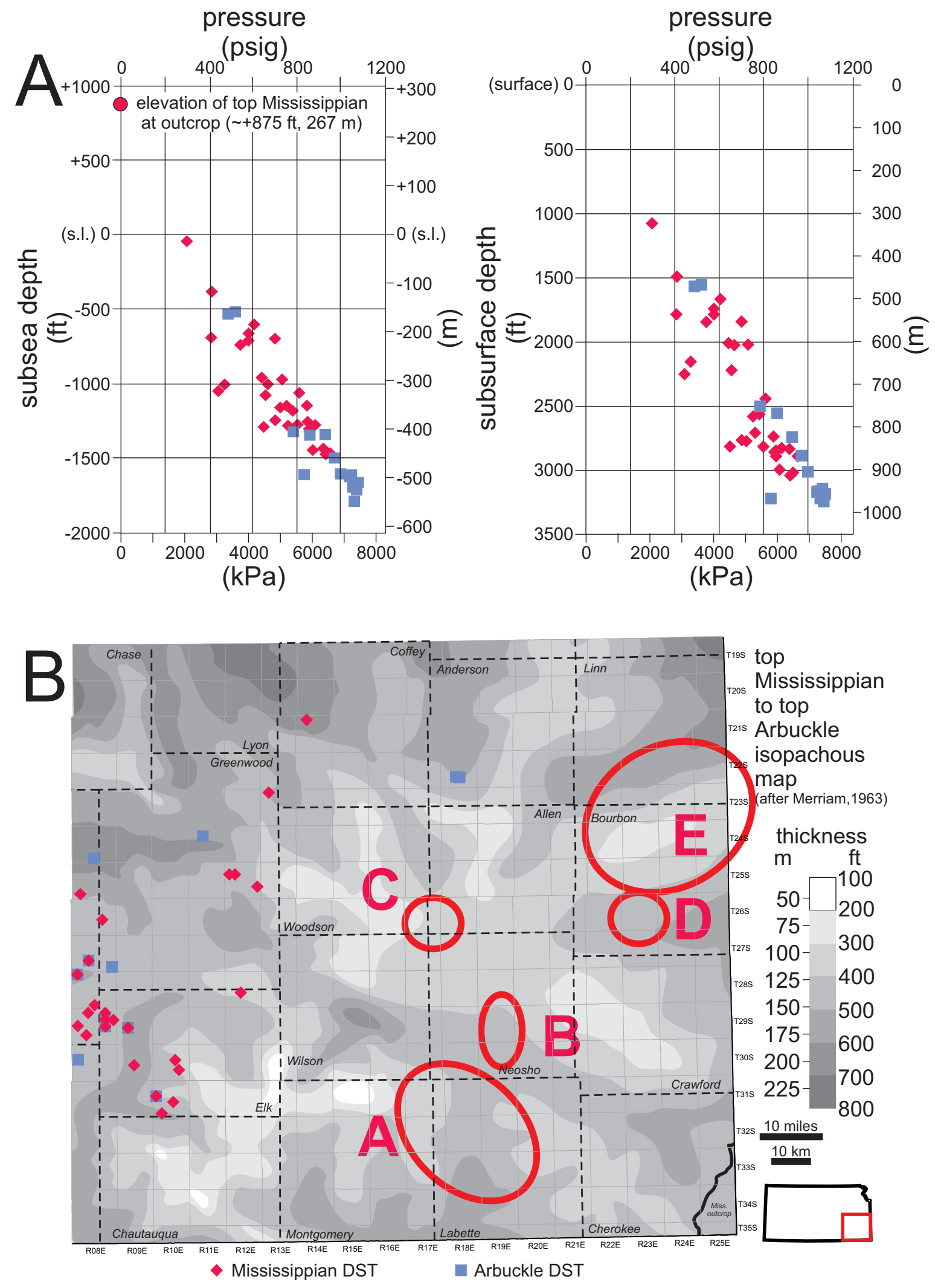

Figure 22. (A) Pressure-depth points from DST shut-in pressures define pressure gradients in southeastern Kansas for the Arbuckle and the Mississippian. Depths with respect to sea level and the surface are illustrated and show that the Arbuckle pressure gradient may be slightly higher than that of the Mississippian. (B) Regional map of the thickness of strata between the top of the Arbuckle and the top of the Mississippian in southeastern Kansas (from Merriam, 1963). DSTs depicted in (A) are mostly concentrated in the western part of the study area. Red ovals indicate geothermal anomalies identified in fig. 12. 
of the Galesburg anomaly is about $450 \mathrm{ft}(137 \mathrm{~m})$ (fig. 22b). Conceivably, especially in a few places where separation of the units is minimal (perhaps $450 \mathrm{ft}$ [137 m] or less), the Arbuckle water may be able to force its way up into the Mississippian by pressure alone if cross-stratigraphic conduits are available.

Present DST and isopachous data are regional in nature, but more detailed mapping than the generalized maps presented in Merriam (1963; see fig. 22) using more recent wells may better identify areas where the thickness of strata between the Arbuckle and Mississippian are abnormally thin. Closely spaced log-derived salinity measurements may also help identify salinity anomalies that may be caused by cross-formational flow. In a few localities, such as northwestern Woodson County and central Wilson County, Mississippian salinities (see fig. 17) can be markedly lower than surrounding and nearby salinities. These localities may be where lower-salinity water from the Arbuckle has also leaked upward into Mississippian strata, but more detailed mapping and salinity determinations are needed to confirm such leakage.

It is not absolutely necessary to invoke a higher pressure in the Arbuckle to force formation water upward into the Mississippian. The higher salinity of the Mississippian water dictates that it will be denser than the less saline Arbuckle water, and this could cause the Mississippian formation water to sink into the Arbuckle, perhaps via a fault conduit. Commensurately, the less dense Arbuckle water would then rise and replace the water lost from the Mississippian. Perhaps a convection cell could facilitate this water movement, where nearby but separate faults could function as upward or downward conduits for formation water exchanged between the Mississippian and Arbuckle.

An empirical density-salinity (ppm TDS) relationship for Kansas Arbuckle waters given in Newell et al. (2020) indicates that water with 17,500 ppm TDS (estimated salinity of Mississippian formation water at the eastern margin of the Galesburg anomaly) would have an approximate density of $1.013 \mathrm{~g} / \mathrm{cm}^{3}$, whereas water with 9,100 ppm TDS (Arbuckle Group) would have a density of $1.007 \mathrm{~g} / \mathrm{cm}^{3}$. Density difference by temperature alone $\left(76^{\circ} \mathrm{F}\left[24.4{ }^{\circ} \mathrm{C}\right]\right.$ at the top of Mississippian strata; $86^{\circ} \mathrm{F}$ $\left[30^{\circ} \mathrm{C}\right.$ ] at the top of Arbuckle strata) would account for freshwater being $0.0015 \mathrm{~g} / \mathrm{cm}^{3}$ heavier in the Mississippian than in the Arbuckle Group (Rumble, 2020). Temperature alone would thus account for about $20 \%$ of the relative buoyancy of Arbuckle formation water. Mixing, of course, would decrease the density difference of the two formation waters, but over geologic time, perhaps large amounts of the more buoyant and warmer Arbuckle formation water could have moved into the Mississippian to account for the Galesburg anomaly.

Oxygen stable isotopic analyses $\left(\delta^{18} \mathrm{O}\right)$ on water samples collected from Pennsylvanian CBM wells over the Galesburg anomaly plot into two separate areas when cross-plotted against salinity (see Kirk et al., 2015), indicating two separate sources of water. In addition, bromine isotope analyses from water from CBM wells in the same region also indicate at least two separate sources of water are present in the lower Pennsylvanian coal seams (R. Stotler, personal communication, 2020). This may indicate that the faulting and associated water movement inferred to account for geothermal and salinity anomalies identified in this report in the Galesburg anomaly may also extend into overlying Pennsylvanian strata.

\section{Petrolia Anomaly}

This anomaly stands out as a small grouping of higher geothermal gradients in T. 26 S., R. 17-18 E., about one township north of an extensive area of lower geothermal gradients (see figs. 11-12). This anomaly is defined solely based on BHT measurements and has no wells surrounding it with which the anomaly can be compared. Ascertaining an origin to this anomaly is thus not possible with present data, and it cannot be discussed further without collection of additional data.

Basement Influence

A regional perspective on the basement rocks underlying all the anomalies can be provided by gravity and aeromagnetic mapping. Deep wells reaching the basement in eastern Kansas are very sparse, so aeromagnetic and gravity maps are the main source of information on basement lithology and structure (fig. 23). The Mound Valley (A) and the Devon (D) anomalies are underlain by northwestsoutheast trending lineations. If these lineations indicate faulting that extends into the Phanerozoic sedimentary section, these two anomalies could be at least partly caused by upward movement of formation water along those faults from the Arbuckle or deeper geologic formations. Oddly, no such lineation underlies the Galesburg anomaly (B), which is the anomaly most likely attributable to such convection (see above). Blackwell and Steele (1989) suggest that radioactive plutons in the Precambrian basement may be the source of the localized heat, but no such plutons can be discerned by gravity and magnetics mapping under the anomalies defined in this paper. 

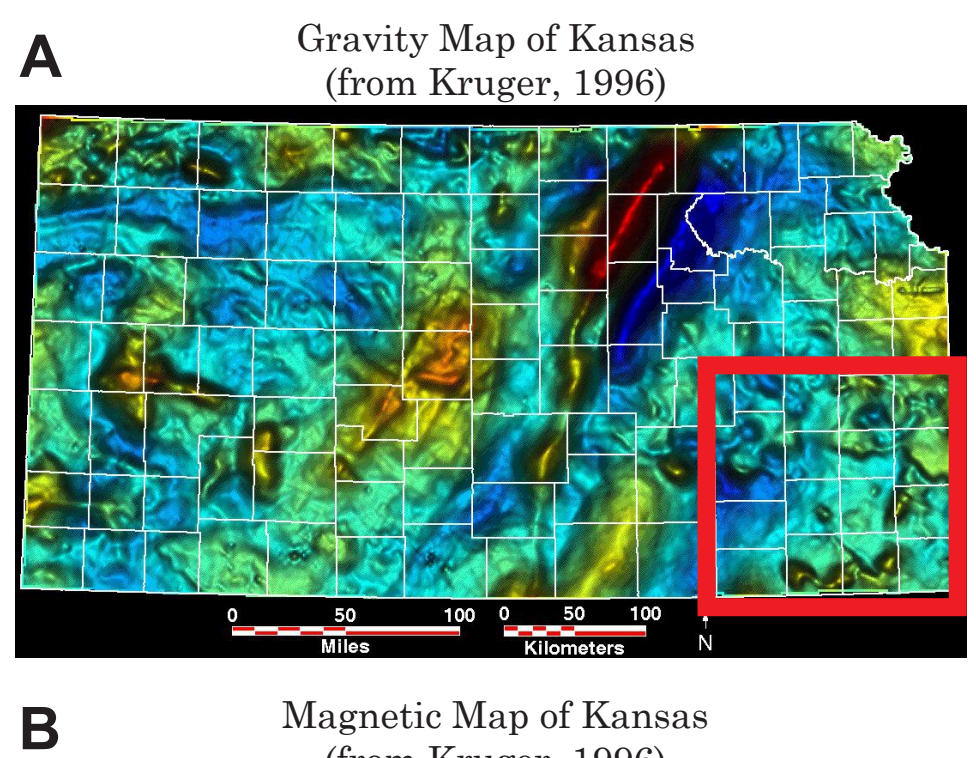

B

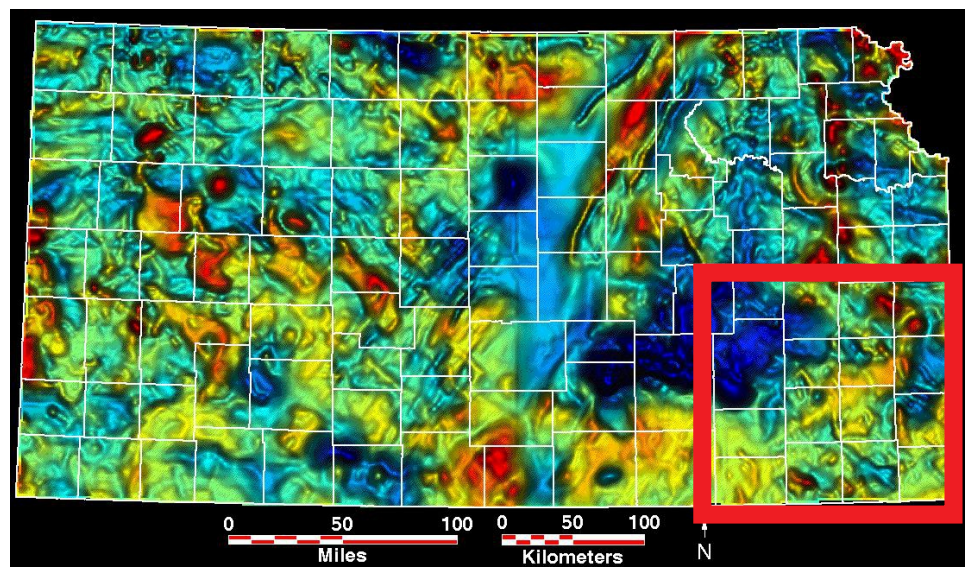

Southeastern Kansas with thermal anomalies

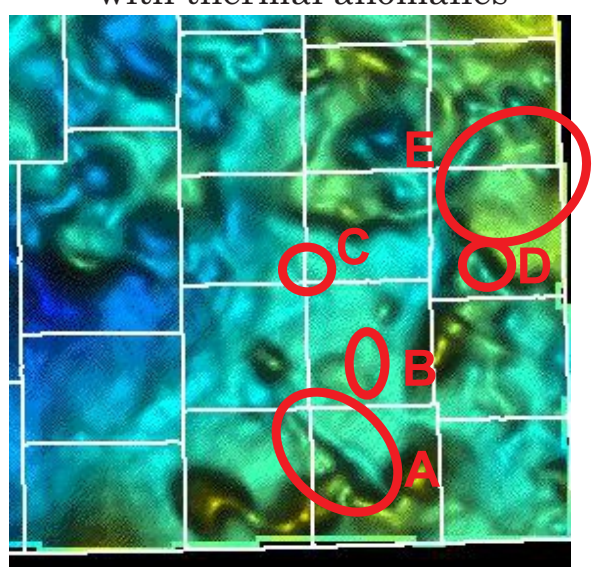

Southeastern Kansas with thermal anomalies

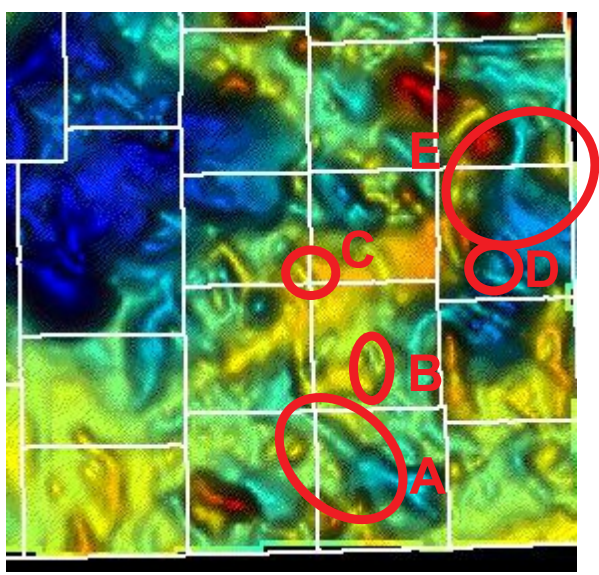

Figure 23. (A) Gravity and (B) magnetic maps of Kansas (from Kruger, 1996). Southeastern Kansas study area is enlarged, with locations of thermal anomalies (from fig. 12) superimposed. These images are displayed with apparent relief created by vertical illumination. In the gravity map, blues represent lowest residual Bouguer gravity values; reds represent highest residual values. Steeper gradients are indicated by darker shading. In the magnetic map, blues represent lowest magnetic values; reds represent highest values. Steeper gradients are indicated by darker shading.

\section{CONCLUSIONS}

The acquisition of about 2,200 continuous temperature logs in southeastern Kansas CBM wells allows for unprecedented detail in understanding subsurface temperatures and geothermal gradients in Mississippian strata. Most of these CBM wells were air drilled and temperature measurements from the logs are likely more closely equilibrated with subsurface formation temperatures than BHT measurements from older muddrilled wells.

Temperatures slightly in excess of $90^{\circ} \mathrm{F}\left(35^{\circ} \mathrm{C}\right)$ in Mississippian strata at depths of about $900 \mathrm{ft}(275 \mathrm{~m})$ have been encountered on the broad eastern flank of the Cherokee basin. These temperatures correspond to geothermal gradients as high as about $60^{\circ} \mathrm{C} / \mathrm{km}$. These geothermal gradients decrease westward and deeper into the basin to levels $\left(20\right.$ to $30^{\circ} \mathrm{C} / \mathrm{km}$ ) more typical for the shallow craton. The new temperature logs, in conjunction with BHTs, allow for precise geographic delineation of several geothermal anomalies on the eastern flank of the Cherokee basin that are correlative with the high temperatures encountered.

The Mound Valley anomaly - one of the larger anomalies covering several townships - correlates to where the overlying Pennsylvanian stratigraphic section contains large cumulative thicknesses of shale. These shales have low thermal conductivity and thus have an insulating effect on the underlying Mississippian limestone. Heat 
is slower to move to the surface, which results in higher temperatures in the Mississippian. Geographic changes in heat flow may also affect temperatures in the Mississippian, but these changes are likely slight and more regional than the thermal anomalies. Westward movement of cooler freshwater off the Ozark dome in Missouri may also mark the boundaries of some thermal anomalies.

Salinity determinations for Mississippian formation water argue against advective movement of hot, saline formation water from the basin axis into the relatively shallow flank of the Cherokee basin or from the Arkoma basin in Oklahoma. However, detailed analysis of salinity in selected areas indicates that one of the smaller thermal anomalies could be caused by upward convective flow of formation water into the Mississippian from the underlying Arbuckle Group. The Arbuckle formation water is less saline and warmer than the formation water in the Mississippian, so buoyancy borne of density and temperature differences could be the driver for the convection. Faults and fractures are inferred to be the conduits by which the formation water moves upward in the stratigraphic column. Inasmuch as the Chattanooga Shale (lying between the Mississippian and Arbuckle) would inhibit convective water movement, regions where the Chattanooga Shale is poorly developed would be more prone to cross-stratigraphic transfer of water and heat.

\section{ACKNOWLEDGMENTS}

The authors thank Dr. Michael Lambert (Kansas State University) and James Stegeman (Colt Energy, retired) for critiquing earlier versions of this article. Dr. Sahir Mohammadi (Kansas Geological Survey) and Dr. Steve Tedesco (Running Foxes Petroleum, Inc.) are thanked for reviewing this article for Midcontinent Geoscience.

\section{REFERENCES}

Allen, P. A., and Allen, J. R., 2013, Basin Analysis; Principles and Application to Petroleum Play Assessment, $3^{\text {rd }}$ edition: London, Wiley-Blackwell, 617 p.

Archie, G. E., 1942, The electrical resistivity log as an aid in determining some reservoir characteristics: Petroleum Technology, v. 5, p. 54-62.

Asquith, G., with Gibson, C., 1982, Basic Well Log Analysis for Geologists: Tulsa, Oklahoma, American Association of Petroleum Geologists, 216 p.

Ball, S. M., 1982, Exploration application of temperatures recorded on log headings - An up-the-odds method of hydrocarboncharged porosity prediction: American Association of Petroleum Geologists, Bulletin, v. 66, no. 8, p. 1,108-1,123.

Barker, C. E., Goldstein, R. H., Hatch, J. R., Walton, A. W., and Wojcik, K. M., 1992, Burial history and thermal maturation of
Pennsylvanian rocks, Cherokee basin, southeastern Kansas: Oklahoma Geological Survey, Circular 93, p. 299-310.

Bateman, R. M., and Konen, C. E., 1977, The log analyst and the programmable pocket calculator: The Log Analyst, v. 18, no. 5, p. 3-11.

Bennison, A. P., 2002, Geologic map of Cherokee County, Kansas: Kansas Geological Survey, Map M-104, scale 1:50,000.

Berendsen, P., and Blair, K. P., 1986, Subsurface structural maps over the Central North American rift system (CNARS), central Kansas, with discussion: Kansas Geological Survey, Subsurface Geology Series 8, 16 p. http: / / www.kgs.ku.edu / Publications / Bulletins /Sub8 / index.html

Berendsen, P., and Blair, K. P., 1991, Interpretive subcrop map of the Precambrian basement in the Joplin 1o x 2o quadrangle: Kansas Geological Survey, Subsurface Geology Series, no. 14, 10 p. http: / / www.kgs.ku.edu / Publications / Bulletins / Sub14/index.html

Bickford, M. E., Harrower, K. L., Nussbaum, R. L., Thomas, J. J., Nelson, B. K., and Hoppe, W. J., 1981, Rb-Sr and U-Pb and geochronology and distribution of rock types in the Precambrian basement of Missouri and Kansas: Geological Society of America, Bulletin, v. 92, no. 6, pt. 1, p. 323-341.

Blackwell, D. D., and Steele, J. L., 1989, Heat flow and geothermal potential in Kansas; in D. W. Steeples, ed., Geophysics in Kansas: Kansas Geological Survey, Bulletin 226, p. 267-291.

Brady, L. L., 1997, Kansas coal resources and their potential for coalbed methane; in G. McMahan, ed., Transactions of the American Association of Petroleum Geologists MidContinent Section Meeting: New Technologies for an Old Frontier: Oklahoma City Geological Society, Oklahoma City, Oklahoma, p. 150-163.

Carlson, M. P., and Treves, S. B., 2005, The Elk Creek Carbonatite, southeast Nebraska - An overview: Natural Resources Research, v. 14, no. 1, p. 39-45.

Carr, J. E., McGovern, H. E., and Gogel, T., 1986, Geohydrology and potential for fluid disposal in the Arbuckle aquifer in Kansas: United States Geological Survey, Open-File Report 86-491, $101 \mathrm{p}$.

Carr, T. R., 2004, Calendar year 2003 - Kansas oil and gas production; An examination of the importance of stripper production: Kansas Geological Survey, Open-File Report 2004-15, 4 p. http: / / www.kgs.ku.edu/PRS / publication/ ofr2004-15/2003Kansas_Oil_and_Gas_Production.pdf

Carr, T. R., Merriam, D. F., and Bartley, J. D., 2005, Use of relational databases to evaluate regional petroleum accumulation, groundwater flow, and $\mathrm{CO}_{2}$ sequestration in Kansas: American Association of Petroleum Geologists, Bulletin, v. 89, no. 12 , p. 1,607-1,627.

Dahlberg, E. C., 1982, Applied Hydrodynamics in Petroleum Exploration: New York, Springer-Verlag, 161 p.

Doveton, J. H., 2004, Applications of estimated formation water resistivities to brine stratigraphy in the Kansas subsurface: Kansas Geological Survey, Open-File Report 2004-63, 20 p.

Doveton, J. H., 2014, Principles of Mathematical Petrophysics: Oxford, U.K., Oxford University Press, 244 p.

Foerster, A., Merriam, D. F., and Davis, J. C., 1996, Statistical analysis of some bottom-hole temperature (BHT) correction 
factors for the Cherokee basin, southeastern Kansas; in D. L. Swindler and C. P. Williams, compilers: Transactions of the 1995 American Association of Petroleum Geologists Mid-Continent Section meeting: Tulsa, Oklahoma, Tulsa Geological Society, p. 3-9.

Foerster, A., Merriam, D. F., and Hoth, P., 1998, Geohistory and thermal maturation in the Cherokee basin (mid-continent, U.S.A.); Results from modeling: American Association of Petroleum Geologists, Bulletin, v. 82, no. 9, p. 1,673-1,693.

Goebel, E. D., 1968a, Cambrian System; in D. E. Zeller, ed., The Stratigraphic Succession in Kansas: Kansas Geological Survey, Bulletin 189, p. 11-13.

Goebel, E. D., 1968b, Mississippian System; in D. E. Zeller, ed., The Stratigraphic Succession in Kansas: Kansas Geological Survey, Bulletin 189, p. 17-21.

Goebel, E. D., 1968c, Ordovician System; in D. E. Zeller, ed., The Stratigraphic Succession in Kansas: Kansas Geological Survey, Bulletin 189, p. 14-15.

Harrison, W. E., Luza, K. V., Prater, M. L., and Cheung, P. K., 1983, Geothermal resource assessment in Oklahoma: Oklahoma Geological Survey, Special Publication 83-1, 42 p.

Jorgensen, D. G., 1989, Paleohydrology of the central United States: United States Geological Survey, Bulletin, 1989-D, 32 p.

Jorgensen, D. G., Helgesen, J. O., and Imes, J. L, 1993, Regional aquifers in Kansas, Nebraska, and parts of Arkansas, Colorado, Missouri, New Mexico, Oklahoma, South Dakota, Texas, and Wyoming - geohydrologic framework: United States Geological Survey, Professional Paper 1414-B, 72 p.

Jorgensen, D. G., Helgesen, J. O., Signor, D. C., Leonard, R. B., Imes, J. L., and Christenson, S. C., 1996, Analysis of regional aquifers in the central midwest of the United States in Kansas, Nebraska, and parts of Arkansas, Colorado, Missouri, New Mexico, Oklahoma, South Dakota, Texas, and Wyoming - summary: United States Geological Survey, Professional Paper 1414-A, 67 p.

Kansas Geological Survey, 2020a, Interactive geologic map of Kansas: http:/ / maps.kgs.ku.edu/state_geology/

Kansas Geological Survey, 2020b, Search for brine analyses in Kansas: http: / / www.kgs.ku.edu/Magellan/Brine/index. html

Kansas State University, 2000, Kansas annual normal temperatures 1971-2000: https: / / www.ksre.k-state.edu/wdl/

Kirk, M. F., Wilson, B. H., Marquart, K. A., Zeglin, L. H., Vinson, D. S., and Flynn, T. M., 2015, Solute concentrations influence microbial methanogenesis in coal-bearing strata of the Cherokee basin, USA: Frontiers in Microbiology, v. 6, 1287. doi: 10.3389/fmicb.2015.01287

Kruger, J. M., 1996, On-line gravity and magnetic maps of Kansas: Kansas Geological Survey, Open-File Report 96-51, http: / / www.kgs.ku.edu/PRS / PotenFld / index.html

Macfarlane, P. A., and Hathaway, L. R., 1987, The hydrogeology and chemical quality of ground waters from the lower Paleozoic aquifers in the Tri-State region of Kansas, Missouri and Oklahoma: Kansas Geological Survey, Ground Water Series 9, $37 \mathrm{p}$.

Merriam, D. F., 1963, The geologic history of Kansas: Kansas Geological Survey, Bulletin 162, 317 p.
Merriam, D. F., 1999, Geologic events affecting geothermal conditions in the Cherokee basin, southeastern Kansas; review and assessment: Transactions of the Kansas Academy of Science, v. 102, no. 3-4, p. 71-82.

Musgrove, M., 1993, Origin, evolution, and mixing of saline and dilute ground waters in three regional flow systems, midcontinent, U.S.A.: M. A. thesis, Department of Geological Sciences, University of Texas, Austin, 225 p.

Newell, K. D., 2017, Kansas coal, CBM, and unconventionals production report: Kansas Geological Survey, Open-File Report 2017-31, 20 p.

Newell, K. D., and Carr, T. R., 2009, Coalbed natural gas production and gas content of Pennsylvanian coal units in eastern Kansas; in T. Carr, T. D'Angostino, W. Ambrose, J. Pashin, and N. C. Rosen, eds., Unconventional Energy Resources: Making the Unconventional Conventional: SEPM Society for Sedimentary Geology, v. 29, p. 353-383.

Newell, K. D, and Merriam, D. F., 2013, Abnormally high geothermal gradients in the Cherokee basin, southeastern Kansas, USA: Kansas Geological Survey, Open-File Report 2013-10, 3 sheets. http: / / www.kgs.ku.edu / Publications / OFR/2013/OFR13_10/index.html

Newell, K. D., Peterie, S., Killion, M., DeArmond, B., Ridley, C., Mandel, R., and Buchanan, R., 2020, Diminishing depth to water in Cambrian-Ordovician Arbuckle Group disposal wells in Kansas: Midcontinent Geoscience, v. 1, no. 1, p. 1-29. https: / / doi.org/10.17161/mg.v1i.15525

Newell, K. D., Watney, W. L., Cheng, S. W. L., and Brownrigg, R. L., 1987, Spatial and stratigraphic distribution of Kansas oil and gas production: Kansas Geological Survey, Subsurface Geology Series 9, 86 p. http: / / www.kgs.ku.edu / Publications / Bulletins /Sub9/index.html

Newell, K. D., and Yoakum, R. L., 2010, Kansas coalbed methane play; in D. F. Merriam, compiler, New Plays and Ways: Kansas Geological Society, Wichita, Kansas, Kansas Oil and Gas Fields, v. VI, p. 105-128.

Roy, R. F., Blackwell, D. D., and Birch, F., 1968, Heat generation of plutonic rocks and continental heat-flow provinces: Earth and Planetary Science Letters, v. 5. , no. 1, p. 1-12.

Rumble, J. R., ed., 2020, Standard density of water; in CRC Handbook of Chemistry and Physics, $101^{\text {st }}$ Edition (Internet Version 2020): Boca Raton, Florida, CRC Press/Taylor \& Francis. https:/ / hbcp. chemnetbase.com/faces / contents / ContentsSearch.xhtml

Schlumberger, 1988, Log interpretation charts: Schlumberger Educational Services, Houston, Texas, 150 p.

Selley, R.C., 1998, Elements of Petroleum Geology, $2^{\text {nd }}$ edition: London, Academic Press, 470 p.

Stavnes, S. A., 1982, A preliminary study of the subsurface temperature distribution in Kansas and its relationship to the geology: M. S. thesis, Department of Geology, University of Kansas, Lawrence, Kansas, 311 p. (available as Kansas Geological Survey, Open-File Report, no. 82-10).

Stavnes, S. A., and Steeples, D. W., 1982a, Geothermal resources of Kansas: United States Department of Energy, Division of Geothermal Energy, 1 sheet, scale 1:500,000.

Stavnes, S. A., and Steeples, D. W., 1982b, Relationships between geology and geothermal gradients in Kansas; in C. A. 
Ruscetta, ed.: Geothermal Direct Heat Program; roundup technical conference proceedings, v. I: University of Utah Research Institute, Earth Sciences Laboratory, Report, no. ESL-98, (NTIS no. DOE/ID/12079-71), p. 88-121.

Steeples, D. W., and Stavnes, S. A., eds., 1982, Assessment of the geothermal resources of Kansas: Kansas Geological Survey, Open-File Report 82-22, 565 p.

Tedesco, S. A, 2021, Unpublished source rock data: Running Foxes Petroleum, 14550 East Easter Avenue, Suite 200, Centennial, Colorado 80112.

United States Energy Information Agency, 2020, Natural gas wellhead price: https: / / www.eia.gov/dnav/ng/hist/ rngwhhdm.htm.

Walton, A. W., Wojcik, K., Goldstein, R. H., and Barker, C. E., 1995, Diagenesis of Upper Carboniferous rocks in the Ouachita foreland shelf in the mid-continent USA; widespread effects of the Variscan-equivalent orogeny: Geologische Rundschau, v. 84, p. $535-551$.
Wojcik, K. M., Goldstein, R. H., and Walton, A. W., 1997, Regional and local controls of digenesis driven by basin-wide flow system; Pennsylvanian sandstones and limestones, Cherokee basin, southeastern Kansas; in I. P. Montanez, J. M. Gregg, and K. L. Shelton, eds., Basin Wide Diagenetic Patterns; Integrated Petrologic, Geochemical, and Hydrologic Conditions: SEPM (Society for Sedimentary Geology), Special Publication, no 7, p. 235-252.

Wojcik, K. M., McKibben, M. E., Goldstein, R. H., and Walton, A. W., 1994, History of diagenetic fluids in a distant foreland area, Middle and Upper Pennsylvanian, Cherokee basin, Kansas, USA; fluid inclusion evidence: Geochimica et Cosmochimica Acta, v. 58, p. 1,175-1,191.

Yarger, H. L., 1983, Regional interpretation of Kansas aeromagnetic data: Kansas Geological Survey, Geophysics Series, no. 1, 35 p. http: / / www.kgs.ku.edu/Publications / Bulletins / Geop1/index.html 


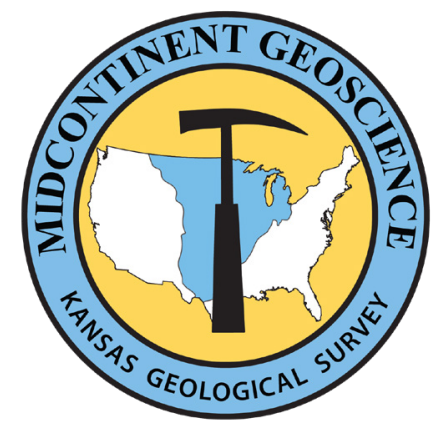

\title{
Midcontinent Geoscience • Volume 2 • December 2021 Tony Layzell — Editor
}

\author{
Section Editor - Franek Hasiuk \\ Technical Editor — Julie Tollefson
}

Suggested citation: Newell, K. D., and Birdie, T. R., 2021, Geothermal anomalies on the eastern flank of the Cherokee basin, southeastern Kansas, USA:

Midcontinent Geoscience, v. 2, p. 54-85.

Midcontinent Geoscience is an open-access, peer-reviewed journal of the Kansas Geological Survey. The journal publishes original research on a broad array of geoscience topics, with an emphasis on the midcontinent region of the United States, including the Great Plains and Central Lowland provinces.

Submission information: https:/ / journals.ku.edu/mg/about/submissions

Kansas Geological Survey 1930 Constant Avenue The University of Kansas Lawrence, KS 66047-3724 785.864.3965

http://www.kgs.ku.edu/

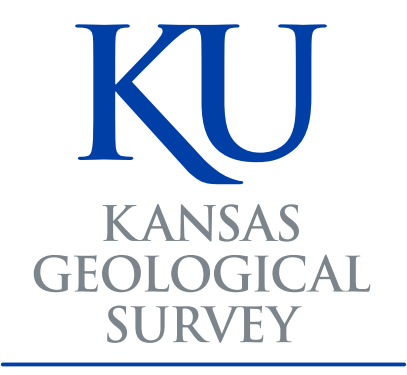

